\title{
Positive Youth Development Programs in Low- and Middle-Income Countries: A conceptual framework and systematic review of efficacy
}




\section{ABSTRACT}

PURPOSE: Positive youth development (PYD) has served as a framework for youth programs in high-income countries since the 1990s and has demonstrated broad behavioral health and developmental benefits. PYD programs build skills, assets and competencies; foster youth agency; build healthy relationships; strengthen the environment; and transform systems to prepare youth for successful adulthood. The goal of this paper was to systematically review the impact of PYD programs in low-and middle-income countries (LMICs).

METHODS: Targeted searches of knowledge repository websites and key word searches of Scopus and Pub Med identified over 21,500 articles and over 3,700 evaluation reports published between 1990 and mid-2016. Ninety-four PYD programs with evaluations in LMICs were identified, of which $35 \mathrm{had}$ at least one experimental or rigorous quasi-experimental evaluation.

RESULTS: Sixty percent of the 35 programs with rigorous evaluations demonstrated positive effects on behaviors, including substance use and risky sexual activity, and/or more distal developmental outcomes, such as employment and health indicators.

CONCLUSIONS: There is promising evidence that PYD programs can be effective in LMICs; however, more rigorous examination with long-term follow-up is required to establish if these programs offer benefits similar to those seen in higher-income countries. 


\section{INTRODUCTION}

Positive youth development (PYD) broadly refers to childhood and adolescent developmental experiences that provide optimal preparation for the attainment of adult potential and well-being [1]. The extensive biological growth, social development and emotional maturation that characterize this period in life [2] take place within a complex web of physical and social environments that shape health, education and developmental outcomes[3]. Programs that promote PYD a) support young people to gain the assets and skills they need to thrive, b) strengthen the environmental context to better support young peoples' development, and c) build the agency of young people so that they may positively influence their own development and the environments in which they live.

The PYD approach was developed in response to the narrow focus on a single problem behavior, often delinquency or substance use. Critiques of this approach recognized that "problem-free" does not mean fully prepared for a healthy adult life [4]. Developmental and prevention scientists as well as practitioners and policy makers reasoned that because many problem behaviors have common predictors, focusing on and measuring a single problem behavior may underestimate the impact of programs that alter these common antecedents [5].

In the early 2000s, progress was made in defining PYD constructs and in clarifying the essential components of a framework [6]. Efforts were made to identify and measure a comprehensive list of developmental assets [7-9]. As described in Table 1, a number of similar approaches were published, each building on the previous work. In 2004 Catalano and colleagues [6] published the first systematic review of PYD programs in the US and found 24 programs with significant improvements in positive development, including academic success and reductions in smoking, drug and alcohol use, school misbehavior, aggressive behavior, violence, truancy, school dropout rates, and high-risk sexual behavior. These programs seek to strengthen various PYD constructs [10] in order to increase positive outcomes and reduce behavioral health problems [11] emphasizing that all youth have strengths, and with appropriate supports can become thriving adults.

\section{Insert Table 1 about here}

Rigorous evaluations of PYD programs in high-income countries have demonstrated that such programs can help young people grow and develop in positive ways in both the short and long term. Areas of positive impact include reduced behavioral health problems, improved mental and physical health, economic development, and overall well-being of adolescents, their families, and their communities [5, 12,13]. Investments in PYD translate to benefits for society by increasing young peoples' connections and contributions to civil society and through supporting successful transitions to adulthood.

This paper investigates the impact of PYD programs in low-and middle-income countries (LMICs). Nearly $90 \%$ of the world's adolescents live in LMICs, where they experience greater early life adversities, reduced educational opportunities and a heavier burden of disease during adolescence as compared to youth in high-income countries [14]. Some approaches tested in high-income countries have been translated for use in LMICs, and the development of context-specific PYD 
approaches has also occurred [15-17]. For example in Hong Kong, P.A.T.H.S. used a universal curriculum delivered by trained teachers showed significant positive outcomes for youth reports using the Chinese PYD scale $[18,19]$. Cross-sectional studies in LMICs have found correlations between PYD constructs and better literacy, numeracy, and the availability of human, social, financial and physical capital to generate income [11]. Youth with greater skills, stronger agency, and enabling environments are more likely to do well in school, be civically engaged, and value diversity [11]. These data provide some evidence that PYD intervention strategies work similarly in LMIC as they do in high income countries and could effectively reduce some hardships for youth in LMICs. However, there has been no comprehensive review of the short- and long-term effects of PYD programs in LMICs, which recently have begun to be tested in experimental studies [20] [21] .

For the purposes of this review a definition of PYD program characteristics was developed based on the literature [22], expert consultations, and key stakeholder surveys. PYD engages youth along with their families, communities and/or governments so thatyouth are empowered to reach their full potential. PYD approaches build skills, assets and competencies; fosteryouth agency; build healthy relationships; strengthen the environment; and transform systems [23, 24].

The goal of this paper is to assess the impact of PYD programs targeting youth aged 10 to 29 in LMICs by systematically reviewing experimental and quasi-experimental evaluations in the literature [23]. The age range is intentionally wide to be inclusive of cultural variation in the transition from childhood to adulthood.

\section{METHODS}

\section{Search Strategy}

This review included peer-reviewed studies and grey literature reports (see Figure 1). To identify studies in the peer reviewed literature the research team selected search terms and tested combinations of these using Scopus and Pub Med to identify peer-reviewed studies with evaluations of PYD programs in LMICs. The search terms were tested by seeing if they captured 10 seminal PYD evaluation papers that had been identified by a team of experts [23]. Over 21,500 peer review papers were identified through this keyword search. For the grey literature, targeted searches of knowledge repository websites hosted by international agencies, including the U.K. Department for International Development, the United Nations, the Inter-American Development Bank, and the World Bank, were supplemented with a survey of over 450 donors and program implementers in LMICs such as Save the Children and UNICEF. This search process identified over 3,700 relevant reports which were then screened in three increasingly in-depth review processes based on title, abstract, and full text. 
The criteria for inclusion were that studies had to: 1) be published between 1990 and mid-2016, 2) be written in English, Spanish or French, 3) include an evaluation in an LMIC, and 4) target youth between 10 and 29 years of age. Additionally, to be included, a program had to address more than one PYD construct or address one PYD construct across multiple socialization domains (e.g. home, school, peers). To this end, a list of relevant PYD constructs was assembled based on an integration of constructs, core concepts [10], the six Cs [1], and previous literature reviews. These constructs were then placed into one of 4 domains: assets, agency, contribution, and enabling environments (see Table 2). It was not require that program

Figure 1. PRISMA diagram of document identification and screening
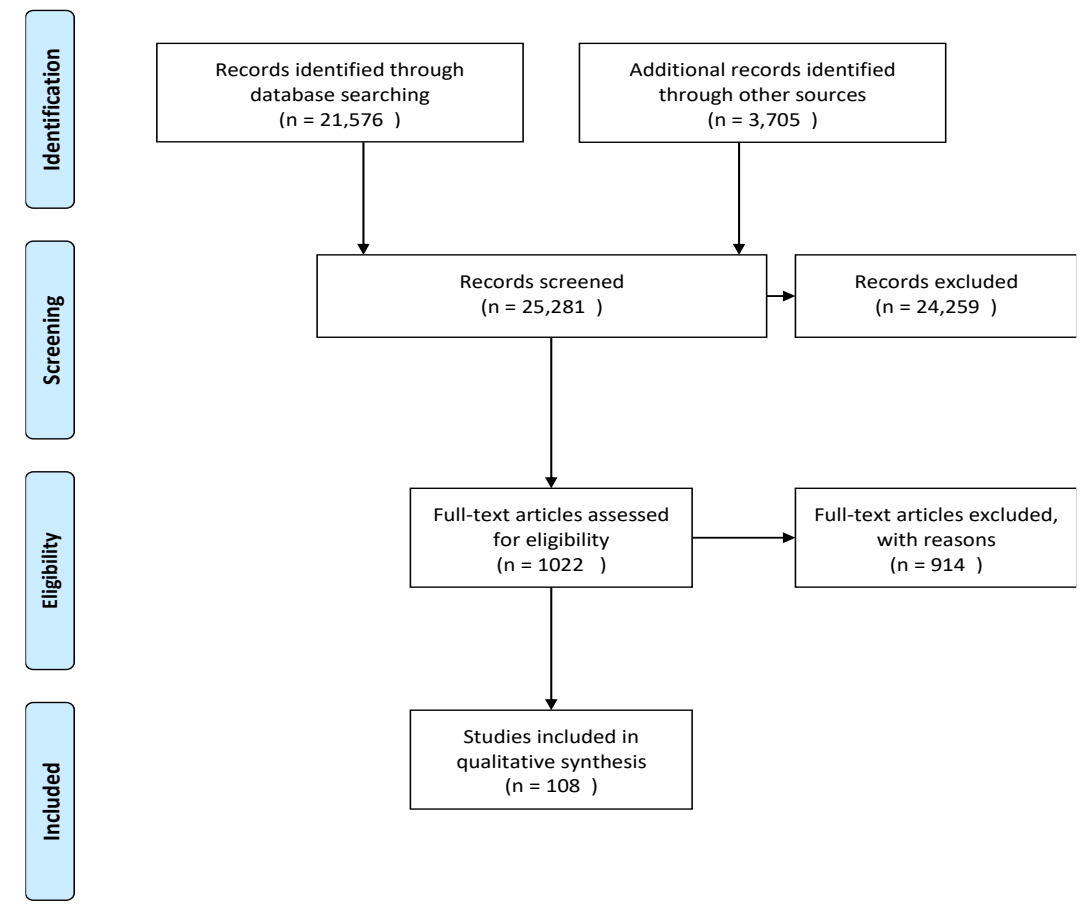

implementers or evaluators identify the program as PYD or measure the PYD constructs they intended to impact.

\section{Insert Table 2 about here}

After title and abstract screening, the full text of 1,022 articles and reports was screened. Sixty-one published articles and 44 reports were included in the final review. These 105 studies reported on 94 different programs. Relevant variables such as program name, country, implementer, target population, program objectives and types of activities, PYD targeted constructs, research design, quality of statistical analyses, and outcomes were coded. An additional person reviewed $10 \%$ of the titles during the title and abstract screening processes to check for consistency in inclusion/exclusion decisions. Percent agreement ranged from 95 to $97 \%$.

\section{Assessing Rigor of Evaluation}

Of the 94 programs identified, 35 had at least one evaluation utilizing a rigorous experimental or quasi-experimental design. Assessment of rigor was conducted using an adapted version of the Checklist for Blueprint Program Evaluation Criteria [25]. Evaluations were considered rigorous if they met at least six of the following eight criteria: the study 1) used an experimental design, 2) used intent to treat analysis, 3) demonstrated that attrition was below $5 \%$ or unrelated to group assignment, sociodemographic characteristics, and baseline measures of the outcomes, 4) the sample was clearly described, 5) the reliability or validity of tests and measures was described, 6) the analysis was done at the proper level, 7) the analysis controlled for baseline outcome measures, and 8) demonstrated baseline equivalence between conditions. Readers interested in promising 
but less rigorously evaluated PYD programs in LMICs can access more information on those programs in the full report [23].

\section{Presentation of Results}

Results are organized with reference to the PYD logic model depicted in Figure 2. For most programs, the ultimate goal is to improve one or more specific positive youth outcomes, such as education, employment, or health. Our logic model illustrates that to impact their ultimate goals, programs address PYD constructs across the four domains (assets, agency, contribution and enabling environment), which in turn lead to changes in the proximal PYD mediators.

Figure 2. Logic model of PYD program impact

\section{Positive Youth Development Programs}

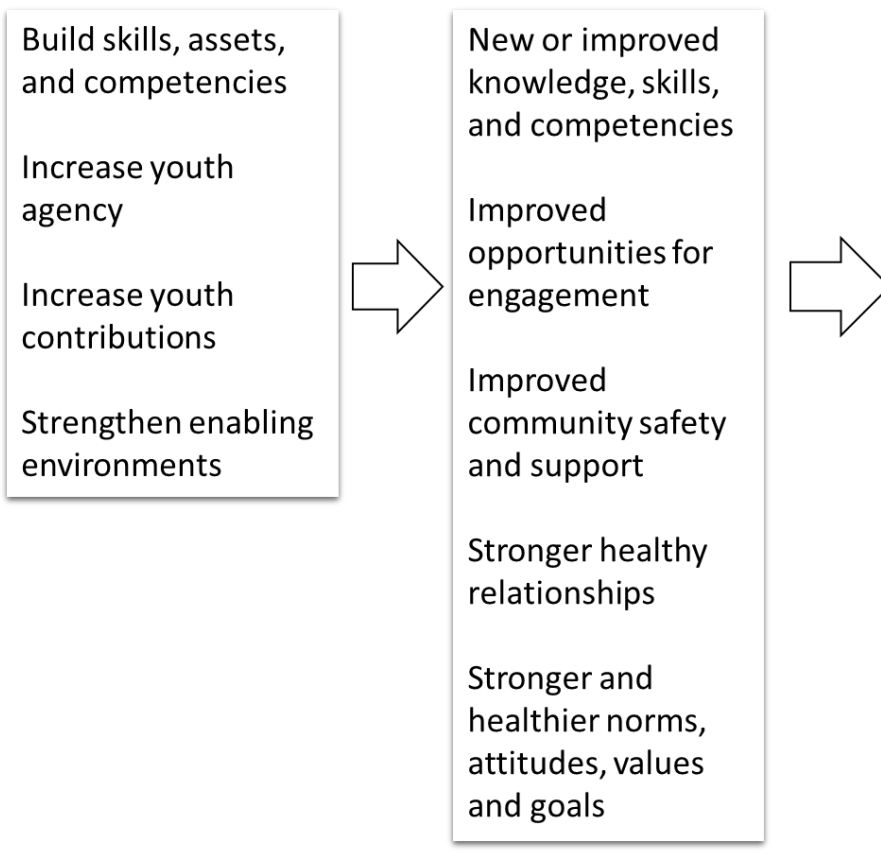

\section{Behavior Change \\ Positive Youth Outcomes}

Reduced

substance use and

delinquency

Greater youth

engagement in

family, school and

community

Reduced violent

behavior

Reduced sexual risk behaviors

Increased service

utilization
Improved mental and physical health

Improved education and employment

Safer (less violent) communities

More inclusive and equitable communities

These changes are often in norms, or in the skills of youth and/or the adults around them. Changes in PYD mediators are then hypothesized to lead to behavior change, such as reduced substance use or increased service utilization. These behavior changes are expected to result in a range of positive outcomes for youth and their communities (i.e., physical health, employment). The logic model was used to organize the presentation of results, rather than to be strictly interpreted as a mediation model, since mediation was almost never tested formally in program evaluations. 


\section{RESULTS}

Table 3 provides summary information on the 35 programs identified with rigorous experimental or quasi-experimental tests of intervention effects. One program (Yo, Pienso, Siento, y Actuo [19]) is included in Table 3 because it was evaluated in a randomized trial, but the school based mental health curriculum reported no significant effectsand is not discussed further. Based on the conceptual model in Figure 2, first, we describe results of efficacy trials in which the significant positive effects are on PYD mediators only. For instance, an evaluation may have demonstrated increased self-efficacy and positive attitudes toward condom use but did not ask about actual condom use after the intervention. Second, we describe programs that demonstrated behavior change (i.e. actual condom use). In some cases, these programs also had measured effects on PYD mediators. Finally, we present results for programs that demonstrated effects on positive youth outcomes. In some cases there is also evidence of effects on PYD mediators and behaviors.

Insert Table 3 about here

\section{PYD mediators}

Ten programs demonstrated effects on PYD mediators only. All of these programs were evaluated within 12 months of completion. One program targeted PYD constructs as primary outcomes. Using a universal curriculum delivered by trained teachers, the Child Resilience program implemented in Uganda [26] showed significant improvements in child and parent reports of child well-being. Eight other school-based programs emphasized life skills and coping strategies using interactive activities in order to impact health risking behaviors. A life-skills training approach to prevent suicide in Cambodia improved relationships as well as life skills [27]. A similar program for girls in Iran to prevent violence and promote gender equality had impacts on attitudes and communication skills [28]. A program in India, Girls First, had similar effects on emotional resilience, self-efficacy and well-being [29]. A life-skills with HIV/AIDS education program delivered by health teachers in South Africa showed improvements in knowledge and attitudes about sexual risk [30]. Similar impacts on knowledge and attitudes have been shown for several programs in other parts of the world including Focus on Kids China [31] , Focus on Kids Vietnam [32], and Exploring the World of Adolescents in Vietnam [33]. A program in Panama [34] that emphasized peer to peer activities influenced knowledge and attitudes related to sexual and reproductive health (SRH). In some cases non-significant findings were reported on targeted outcomes [27, 29, 30, 32], and in one case, there were unexplained significant negative effects on some measures of targeted knowledge and beliefs[33]. One program with impact on PYD mediators was not delivered in school and was exclusively for adolescent boys. In India, the Parivartan program, which trained cricket coaches to facilitate gender topic discussions with their players, showed a significant shift toward more respectful attitudes toward women and greater willingness to intervene when witnessing disrespectful behavior toward women, but had no impact on self-reported behaviors [35]. 


\section{Behavioral outcomes}

Eleven programs demonstrated impacts on youth behaviors but not more distal positive youth outcomes. With two exceptions [36, 37] all evaluations were conducted within 12 months of program completion. Let Us Protect Our Future, a school-based program in South Africa [38, 39], included sessions in mixed-sex groups on gender norms and homework assignments to involve parents in the curriculum. The program reduced self-reported risky sexual behaviors, which were both mediated and moderated by parent involvement variables. The comparison condition was a cognitive-behavioral health promotion program delivered in the same format which had some impact on diet and exercise, but not sexual behavior or substance use [40]. Another program in South Africa, Wake Up, delivered in mixed-sex groups by university graduate students, also showed a reduction in most, but not all of the self-reported risky sexual behaviors [41]. The Adolescent Sexual and Reproductive Health (ASRH) project in Ghana used a multi-level strategy that involved stakeholder meetings, health worker training, in-school curriculum, and peer outreach to youth not in school. In a rare 3 year follow up, significant increases were reported for use of most, but not all, health services as well as SRH knowledge and attitudes [37]. A program in Malaysia [42] using peer to peer activities influenced knowledge and attitudes related to SRH and reduced self-reported HIV risk behavior related to substance use. The Responsible, Engaged, and Loving (REAL) Fathers Initiative in Uganda focused on mentoring teen fathers, teaching non-violent discipline practices and supporting relationship-building activities between fathers and young children (1-3 years of age) [36]. This program had no effect on gender norms, but reduced self-reported domestic violence, increased communication and positive parenting skills and improved attitudes toward non-violent discipline reported at the 18 month follow-up. The Questscope project in Jordan used activities in single-sex group meetings ( $85 \%$ of the sample was male) and reported significant reduction of self-reported conduct problems, although no effect on the intended PYD mediators, primarily self-efficacy [43].

A school-based life skills training approach in India had positive effects on self-esteem, perceived coping, adjustment in school, and pro-social behavior [44]. A similar program in India, STEP II, combined HIV and alcohol use prevention in school settings and showed no overall effects [45], but significant effects on communication skills for girls only. Two school-based programs designed specifically to prevent substance use showed significant effects on self-reported substance use. In Mexico, the keepin' it REAL program used a teacher-led curriculum that trained students in refusal skills $[46,47]$, but achieved limited impact on use of alcohol and only for girls. In Romania, peer-led discussions using video clips increased self-efficacy and reduced substance use [48].

\section{Positive Youth Outcomes}

Fourteen of the 35 programs evaluated reported effects on positive youth outcomes related to physical and mental health, income and employment, and gender equality. Six of these also reported effects on PYD mediators (i.e. knowledge, norms, and skills) and/or behaviors (i.e., risky sexual behavior, substance use, interpersonal violence). Most of these evaluations included longer term follow-ups, and two had follow-ups after many years $[49,50]$. 
In the area of physical health, we found three programs in sub-Saharan Africa. A randomized control trial of Stepping Stones in rural South Africa showed improved physical health as well as behavior change. First developed in Uganda [51], and implemented in many countries, Stepping Stones uses a multi-level approach that targets individuals, couples, households and communities. The South Africa program [52] used a manual with 13 core sessions that covered sexual health along with gender-based violence, dealing with grief and loss, and building assertiveness skills. Jewkes and colleagues $[52,53]$ found improved health by reducing risk of herpes simplex virus 2 acquisition by one-third over two years of follow-up, but did not reduce the incidence of HIV infection. The program also changed behavior by reducing the perpetration of intimate partner violence reported by male participants, but had no impact on risk behaviors of women. Creating Futures combined a broad economic empowerment intervention with the original Stepping Stones package. It demonstrated effects on many, but not all, of the intended outcomes. The study found average earnings of participants were more than double that of controls [54]. Young men and women in the intervention scored significantly better on tests of gender equality attitudes, men reported significantly reduced controlling practices in their relationships, and the prevalence of depression symptoms and suicidal thoughts among men decreased significantly relative to controls. Women reported less interpersonal violence in the prior three months thank controls. In Uganda, a version of Street Smart (a multi-session HIV prevention program delivered in small groups) was combined with vocational training and apprenticeships with employers who received training in topics pertinent to employing young people. The addition of employment support improved employment, quality of life, and perceived social support while reducing self-reported delinquent behavior over two years [55].

Two programs had limited impact on mental health. In Palestine, a universal school-based intervention known as Teaching Recovery uses cognitive behavioral therapy techniques combined with homework involving parents and family members - to reduce the detrimental impact of war. An evaluation showed reduced post-traumatic stress disorder diagnoses but no impact on overall symptoms and effects on other measures of distress [56]. A program in the Democratic Republic of the Congo designed specifically for war-affected youth [57] combining life skills with relaxation techniques, and including participation by the youth's caregiver, showed improvements in emotional stability, but no impact on depression or anxiety.

Four programs demonstrated effects related to employment. TheYes Youth Can program in Kenya combined school and community organization strategies. Participants reported increased likelihood of asset ownership but not income, improvements in self-efficacy and increased perceptions of community supportiveness [58]. Three programs designed to increase employment provided vocational training as well as work-related soft skills such as communication and problem-solving. Akazi Kanoze in Rwanda demonstrated positive effects on skills as well as employment, but effects were limited to women and those with lower income [59]. Pro Joven in Peru increased earnings, the likelihood of employment and paid employment, having employerprovided health insurance and pensions [60] over an 18 month follow up period. Effects were strongest for females and younger participants (14 to 18 years old). The Juventud y Empleo program in the Dominican Republic included internships and demonstrated increased contractual employment, higher monthly earnings, and reduced length of unemployment $[49,61]$ over 2 years 
and increased formal employment over 6 years. There were no long term impacts on earnings.

Most of the programs included in this review were designed for both males and females, although several provided services, training, and social opportunities specifically to girls. In Zimbabwe, Supporting Adolescent Orphan Girls provided both material support and mentorship. It significantly improved SRH knowledge and changed attitudes about gender norms, significantly reduced the likelihood of early marriage, and improved school retention and food security over five years [50, 62]. No effects were observed on HIV or HSV. The SHAZ program in Zimbabwe combined life-skills training, health education, vocational training and micro grants to out-of-school girls aged 17 to 19. Although no effects were found on sexual risk behaviors or social support, there were significant increases in food security and the likelihood of having their own income after two years [63]. A similar approach was used in the Empowerment and Livelihood for Adolescents (ELA) program in Uganda [64] where girls aged 14 to 20 formed community clubs in which life-skills and vocational training and recreational and social activities were provided in a safe environment. Significant improvements were reported for SRH knowledge, consistent condom use, selfemployment (but not wage employment), reduced early marriage, and reduced reports of having sex unwillingly in the past year. In Bangladesh, BALIKA used a girls-only community club approach to provide educational supports through tutoring, gender awareness, livelihood skills, and community engagement. A significant reduction in child marriage and increased working for pay was reported by girls in the program [65]. Other indicators of economic independence and use of birth control were not influenced.

Our search identified a single program designed to improve physical activity and fitness. This school based intervention, Activital in Ecuador included teacher lead activities, parent workshops, and installation of a new walking trail at the school and demonstrated some impact on objective measures of physical fitness after 2 years, but no effects on screen time or body mass index [66].

\section{DISCUSSION}

The conceptual framework developed for this review makes explicit the role that PYD constructs play in the logic model of many PYD programs. All of the programs included in this review used multiple pathways within this model, focusing on at least 2 , and in most cases 3 or 4 of the general PYD domains: assets, agency, contribution, and enabling environment. We identified promising evidence for the effectiveness of a PYD approach in influencing PYD mediators, behaviors and positive outcomesin LMICs. However, rigorous experimental or quasi-experimental evaluations made up less than forty percent of the evaluations that we found, and very few reported results beyond short-term outcomes. Almost all of the evaluations produced mixed results with some evidence supporting positive impact and some non-significant findings for hypothesized outcomes.

School curricula delivered in weekly sessions by trained school or project staff demonstrated some success improving knowledge, attitudes and soft skills [27, 30, 32, 34]. These programs usually 
included facilitated interactions and activities to support peer-to-peer involvement [42]. Almostall of the programs reported impacts on PYD mediators. When skill-building was a target of the intervention, improved skills (both specific and general) were often reported. In a few cases, behavior and mental health outcomes were measured, but were not significantly influenced [27, 29, 30].

We also identified interventions designed specifically for vulnerable populations, such as women and girls $[28,29,32,45,62,63,65,67]$ and war-affected youth $[56,57]$. However, there were no programs designed to address several other vulnerable subgroups, including sexual minority youth and youth with disabilities who have been shown to be at elevated risk for victimization, unemployment and poor health outcomes [68-71]. The evidence we did find supports using PYD approaches with vulnerable or underserved populations to reduce disparities in assets, agency, contribution, and enabling environments. This suggests that when disparities in PYD constructs are narrowed, disparities in positive youth outcomes such as income and health can also be reduced $[37,58-63,65]$.

A number of programs combined efforts to reduce behavioral health problems (e.g. sexual or substance-related) and improve gender equality, education or employment with positive effects $[50,54,55,61,62,67]$. Most of these programs showed some impact on PYD constructs, behavior change, and positive youth outcomes such as income, food security, or reductions in child marriage [65]. This includes two female-only programs that addressed girls' particular disadvantages in education, employment, and control over their sexual risk.

Of the programs with rigorous evaluations, the programs that intentionally targeted several related positive youth outcomes are the most promising for larger-scale implementations. Many of these programs encouraged youth engagement in the implementation of the program through creating groups, participating in decisions about topics and activities within the programs, and through providing peer support. Direct involvement of young people in developing new programs was less evident, but there is growing evidence that youth involvement in every level of decision-making could improve program outcomes [72].

\section{Limitations}

Most systematic reviews start with a single outcome of interest or a relationship between a class of interventions and a single outcome (e.g. family-oriented programs designed to prevent violence). For this review the search terms used to identify different PYD constructs were many and varied; a large developmental period was covered (i.e., childhood, adolescence, and young adulthood); and diverse types of interventions across a broad set of outcomes were included. As a result of this intentionally broad scope, a large number of titles were retrieved and screened. The number and complexity of search terms may have resulted in missing some relevant studies.

Besides the limitations encountered in conducting the review itself, there are limitations in the interpretation of results found in these evaluations. In most cases non-significance results were reported along with significant ones, but it is possible that some intended effects were found to be non-significant but not reported, leading to an overly positive impression of the program. Program 
descriptions are limited to what was available in reports and publications making it impossible to make stronger statements about which program features or characteristics lead to positive results.

\section{Recommendations}

Expand specific PYD program models that have demonstrated efficacy across multiple outcomes. There is evidence that programs that combine SRH and HIV prevention with workforce readiness and violence reduction obtain positive outcomes related to employment and reductions in genderbased violence, as well as other behavioral health problems. By intentionally targeting several predictors of problem behaviors and outcomes across multiple areas (health, employment, and education), PYD programs hold the promise of effectively increasing the return on prevention investments [73]. PYD programs ideally strengthen multiple PYD mediators, preferably with multiple targets (e.g., youth, teachers, civic leaders) using multiple strategies. A strong evaluation of program impact should include measures of all of the potential outcomes related to the PYD mediators targeted in the intervention.

Conduct rigorous randomized controlled trials on promising programs with longer-term follow-up. Once a program has been shown to be feasible and have promising short-term impact, it is essential to investigate longer term follow-up in order to identify programs that have lasting effects.

Design evaluations to test for the mediating effect of PYD constructs on targeted behaviors and intended outcomes. In only one case did we find an evaluation focused on demonstrating the mechanisms by which the program had its impact on outcomes [38]. In order to build knowledge on how PYD might be having a positive impact on the lives of youth in LMICs we need to demonstrate what levers are working in PYD programs.

Assess program impact on typically excluded high-risk youth. None of the 35 programs we identified with rigorous evaluations were designed to address sexual minorities or young people with disabilities. While a PYD program may be especially beneficial to various high-risk youth groups, we cannot assume current programs meet their needs.

Include benefit/cost data in program evaluations. None of the 94 program evaluations we identified provided evidence of cost-effectiveness. Increasingly, this kind of information is needed to assess whether large-scale implementation is desirable [74].

\section{Implications and Contribution summary statement}

The programs in this review provide emerging evidence that PYD interventions can be applied in very different contexts. The results include positive impacts across a range of outcomes (e.g. health, employment, civic engagement), and may be promising for increasing gender equality. While there is promise for the PYD approach [6], there is still much to be learned. 


\section{References}

1. Lerner, R.M., Developing civil society through the promotion of positive youth development. Journal of Developmental and Behavioral Pediatrics, 2000. 21(1): p. 48-49.

2. Dahl, R.E., The developmental neuroscience of adolescence: Revisiting, refining, and extending seminalmodels. Developmental Cognitive Neuroscience, 2016. 17: p. 101-102.

3. Raudenbush, S.W. and A.S. Bryk, Hierarchical linear models: Applications and data analysis methods. 2nd ed. 2002, Newbury Park, CA: Sage.

4. Pittman, K.J., R. O'Brien, and M. Kimball, Youth development and resiliency research: Making connections to substance abuse prevention. Report prepared for The Centerfor Substance Abuse Prevention. 1993, Washington, DC: Center for Youth Development and Policy Research.

5. Catalano, R.F., et al., Positive youth development in the United States: Research findings on evaluations of positive youth development programs. Prevention and Treatment, 2002. 5(1): p. Article 15, June 24, 2002.

6. Catalano, R.F., et al., Positive youth development in the United States: Research findings on evaluations of positive youth development programs. The Annals of the American Academy of Political and Social Science, 2004. 591(1): p. 98-124.

7. Benson, P.L., J. Galbraith, and P. Espeland, What kids need to succeed:Proven, practical ways to raise good kids. 1998, Minneapolis, MN: Free Spirit Publishing.

8. Scales, P.C. and N. Leffert, Developmental assets: A synthesis of the scientific research on adolescent development. Developmental assets: A synthesis of the scientific research on adolescent development. 1999, Minneapolis, MN, US: Search Institute. xvi, 279-xvi, 279.

9. Scales, P.C., et al., Contribution of DevelopmentalAssets to the Prediction of Thriving Among Adolescents. Applied Developmental Science, 2000. 4(1): p. 27-46.

10. Catalano, R.F., J.W. Toumbourou, and J.D. Hawkins, Positive youth development in the United States: History, efficacy and links to moral and character education, in Handbook of moral and charactereducation, L. Nucci, D. Narvaez, and T. Krettenauer, Editors. 2014, Routledge: New York and London. p. 423-440.

11. Scales, P.C., et al., The dimensions of successfulyoung adult development: A conceptualand measurement framework. Applied Developmental Science, 2016. 20(3): p. 150-174.

12. Gavin, L.E., et al., A review of positive youth development programs that promote adolescent sexual and reproductive health. Journal of Adolescent Health, 2010. 46(3 Suppl.)(3): p. S75-S91.

13. Patton, G.C., et al., From Advocacy to Action in GlobalAdolescent Health. Journal of Adolescent Health, 2016. 59(4): p. 375-377.

14. Patton, G.C., et al., Global patterns of mortality in young people: A systematic analysis of population health data. Lancet, 2009. 374(9693): p. 881-892.

15. Catalano, R.F., et al., Worldwide application prevention science in adolescent health. The Lancet, 2012. 379(9826): p. 1653-1664.

16. Guo, J.L., et al., Prevention of illicit drug use through a school-based program: Results of a longitudinal, cluster-randomized controlled trial. Journal of Adolescent Health, 2015. 56(3): p. 314-322.

17. Wong, M.C.S., et al., A comparative study on resilience level between WHO health promoting schools and other schools among a Chinese population. Health Promotion International, 2009. 24(2): p. 149-155. 
18. Shek, D.T.L., et al., Positive youth development programs targeting students with greater psychosocialneeds: Subjective outcome evaluation. TheScientificWorldJOURNAL, 2008. 8: p. 7382.

19. Shek, D.T.L. and M.S. Ma Cecilia, Impact of Project P.A.T.H.S. on adolescent developmental outcomes in Hong Kong: Findings based on seven waves of data. International Journal of Adolescent Medicine and Health, 2012. 24(3): p. 231-244.

20. World Bank Washington, D.C., World development report 2007: Development and the next generation. 2007.

21. United States Agency for International Development, Youth in development policy. 2012: Washington, DC.

22. Roth, J.L. and J. Brooks-Gunn, Youth development programs: Risk, prevention and policy. Journal of Adolescent Health, 2003. 32(3): p. 170-182.

23. Alvarado, G., et al. A systematic review of positive youth development programs in low-and middle-income countries. 2017; Available from: https://pdf.usaid.gov/pdf_docs/PA00MR58.pdf.

24. Hinson, L., et al. Positive youth development measurement toolkit. A practical guide for implementers of youth programs. 2016; Available from:

http://www.youthpower.org/resources/positive-youth-development-measurement-toolkit.

25. Centerfor the Study and Prevention of Violence. Blueprintsfor Violence Prevention. 2011 May 9, 2011]; Available from: www.colorado.edu/cspv/blueprints.

26. Ager, A., et al., The impact of the school-based PsychosocialStructured Activities (PSSA) program on conflict-affected children in northern Uganda. Journal of Child Psychology and Psychiatry, 2011. 52(11): p. 1124-1133.

27. Jegannathan, B., K. Dahlblom, and G. Kullgren, Outcome of a school-based intervention to promote life-skills among young people in Cambodia. Asian Journal of Psychiatry, 2014. 9: p. 7884.

28. Soleiman Ekhtiari, Y., et al., The effect of an intervention based on the precede-proceed modelon preventive behaviors of domestic violence among iranian high schoolgirls. Iranian Red Crescent Medical Journal, 2012. 15(1): p. 21-28.

29. Leventhal, K.S., et al., Building psychosocial assets and wellbeing among adolescent girls: $A$ randomized controlled trial. Journal of Adolescence, 2015. 45: p. 284-295.

30. James, S., et al., The impact of an HIV and AIDS life skills program on secondary schoolstudents in KwaZulu-Natal, South Africa. AIDS Education and Prevention, 2006. 18(4): p. 281-294.

31. Li, S., et al., Evaluation of a school-based HIV/AIDS peer-led prevention programme: The first intervention trial for children of migrant workers in China. International Journal of STD \& AIDS, 2010. 21(2): p. 82-86.

32. Kaljee, L.M., et al., Effectiveness of a theory-based risk reduction HIV prevention program for rural Vietnamese adolescents. AIDS Education and Prevention, 2005. 17(3): p. 185-199.

33. Pham, V., et al., Evaluation of three adolescent sexual health programs in Ha Noi and Khanh Hoa Province, Vietnam. AIDS Research and Treatment, 2012. 2012: p. 986978.

34. Aramburú, M.G., et al., Educational impact of peer-intervention on the knowledge and attitudes about HIV/AIDS in adolescents in Panama. International Journal of Adolescent Medicine and Health, 2012. 24(2): p. 135-141.

35. Miller, E., et al., Evaluation of a gender-based violence prevention program for student athletes in Mumbai, India. Journal of Interpersonal Violence, 2014. 29(4): p. 758-778.

36. Ashburn, K., et al., Evaluation of the Responsible, Engaged, and Loving (REAL) Fathers Initiative on physicalchild punishment and intimate partner violence in Northern Uganda. Prevention Science, 2017. 18(7): p. 854-864. 
37. Aninanya, G.A., et al., Effects of an adolescent sexual and reproductive health intervention on health service usage by young people in northern Ghana: A community-randomised trial. PLoS One, 2015. 10(4): p. e0125267.

38. O'Leary, A., et al., Moderation and mediation of an effective HIV risk-reduction intervention for South African adolescents. Annals of Behavioral Medicine, 2012. 44(2): p. 181-191.

39. Jemmott, J.B., et al., School-based randomized controlled trial of an hiv/std risk-reduction intervention for south african adolescents. Archives of Pediatrics \& Adolescent Medicine, 2010. 164(10): p. 923-929.

40. Jemmott lii, J.B., et al., Cognitive-behavioural health-promotion intervention increases fruit and vegetable consumption and physical activity among South African adolescents: a clusterrandomised controlled trial. Psychology \& Health, 2011. 26(2): p. 167-185.

41. Heeren, G.A., et al., A randomized controlled pilot study of an HIV risk-reduction intervention for sub-Saharan African University Students. AIDS and Behavior, 2013. 17(3): p. 1105-1115.

42. Ibrahim, N., et al., Effectiveness of peer-led education on knowledge, attitude and risk behavior practices related to HIV among students at a Malaysian public university--a randomized controlled trial. Preventive Medicine, 2012. 55(5): p. 505-510.

43. Morton, M.H. and P. Montgomery, Empowerment-basednon-formaleducation for Arab youth: $A$ pilot randomized trial. Children and Youth Services Review, 2012. 34(2): p. 417-425.

44. Srikala, B. and K.V. Kishore Kumar, Empowering adolescents with life skills education in schoolsSchool mental health program: Does it work? Indian Journal of Psychiatry, 2010. 52(4): p. 344349.

45. Chhabra, R., et al., Adaptation of an alcohol and HIV school-based prevention program for teens. AIDS and Behavior, 2010. 14 Suppl 1: p. S177-S184.

46. Marsiglia, F.F., et al., Short-term effects on substance use of the keepin' it REAL pilot prevention program: Linguistically adapted for youth in Jalisco, Mexico. Prevention Science, 2014. 15(5): p. 694-704.

47. Marsiglia, F.F., et al., Long-term effects of the keepin' it REAL model program in Mexico: Substance use trajectories of Guadalajara middle schoolstudents. Journal of Primary Prevention, 2015. 36(2): p. 93-104.

48. Lotrean, L.M., et al., Evaluation of a peer-led smoking prevention programmefor Romanian adolescents. Health Education Research, 2010. 25(5): p. 803-814.

49. Ibarraran, P., et al. Experimentalevidence on the long-term impacts of a youth training program. IZA Discussion Paper No. 9136. 2015; Available from: https://ssrn.com/abstract=2655085.

50. Hallfors, D.D., et al., The impact of schoolsubsidies on HIV-related outcomes among adolescent female orphans. Journal of Adolescent Health, 2015. 56(1): p. 79-84.

51. Welbourn, A., Stepping stones. A packagefor facilitators to help you run workshops within communities on HIV/AIDS communication and relationship skills. 1995.

52. Jewkes, R., et al. , Impact of Stepping Stones on incidence of HIV and HSV-2 and sexual behaviour in rural South Africa: Cluster randomised controlled trial. BMJ, 2008. 337: p. a506.

53. Jewkes, R., K. Wood, and N. Duvvury, 'I woke up after I joined Stepping Stones': Meanings of an HIV behavioural intervention in rural South African young people's lives. Health Education Research, 2010. 25(6): p. 1074-1084.

54. Jewkes, R., et al., Stepping Stones and Creating Futures intervention: Shortened interrupted time series evaluation of a behavioural and structural health promotion and violence prevention intervention for young people in informalsettlements in Durban, South Africa. BMC Public Health, 2014. 14: p. 1325.

55. Rotheram-Borus, M.J., et al., Vocational training with HIV prevention for Ugandan youth. AIDS and Behavior, 2012. 16(5): p. 1133-1137. 
56. Qouta, S.R., et al., Intervention effectiveness among war-affected children: A cluster randomized controlled trial on improving mental health. Journal of Traumatic Stress, 2012. 25(3): p. 288-298.

57. O'Callaghan, P., et al., A pilot study of a family focused, psychosocial intervention with warexposed youth at risk of attack and abduction in north-eastern Democratic Republic of Congo. Child Abuse \& Neglect, 2014. 38(7): p. 1197-207.

58. NORAC. Yes, Youth Can! Impact evaluation report. 2014; Available from: http://pdf.usaid.gov/pdf_docs/PA00JZQX.pdf.

59. Alcid, A. A randomized controlled trial of Akazi Kanoze youth in rural Rwanda. Report submitted to USAID. 2014; Available from: https://main.edc.org/sites/default/files/uploads/RCTReport.pdf.

60. Diaz, J.J. and D. Rosas. Impact evaluation of the job youth training program Projoven. IDB Working Paper Series NoIDB-WP-693. 2016; Available from:

https://publications.iadb.org/bitstream/handle/11319/7615/Impact-Evaluation-of-the-JobYouth-Training-Program-Projoven.pdf?sequence $=1$.

61. Ibarraran, P., et al., Life skills, employability and training for disadvantaged youth: Evidence from a randomized evaluation design. IZA Journal of Labor \& Development, 2014. 3(1): p. 10.

62. Hallfors, D., et al., Supporting adolescent orphangirls to stay in schoolas HIV risk prevention: Evidence From a randomized controlled trial in Zimbabwe. American Journal of Public Health, 2011. 101(6): p. 1082-1088.

63. Dunbar, M.S., et al., The SHAZ! project:Results from a pilot randomized trial of a structural intervention to prevent HIV among adolescent women in Zimbabwe. PLoS One, 2014. 9(11): p. e113621.

64. Bandiera, O., et al. Women's empowerment in action: Evidence from a randomized control trial in Africa. 2017; Available from: http://www.ucl.ac.uk/ uctpimr/research/ELA.pdf.

65. Amin, S., et al. Delaying child marriage through community-based skills-development programs forgirls. Results from a randomized controlled study in rural Bangladesh . 2016; Available from: http://www.popcouncil.org/uploads/pdfs/2016PGY_BALIKA_EndlineReport.pdf.

66. Andrade, S., et al., A school-based intervention improves physical fitness in Ecuadorian adolescents: A cluster-randomized controlled trial. The International Journal of Behavioral Nutrition and Physical Activity, 2014. 11: p. 153.

67. Luseno, W., et al., HIV infection and related risk behaviors: Does schoolsupport level the playing field between orphans and nonorphans in Zimbabwe? AIDS Care, 2015. 27(9): p. 1191-1195.

68. Russell, S.T., et al., Indicators of victimization and sexual orientation among adolescents: Analyses from youth risk behavior surveys. American Journal of Public Health, 2014. 104(2): p. 255-261.

69. Jones, L., et al., Prevalence and risk of violence against children with disabilities: A systematic review and meta-analysis of observational studies. The Lancet, 2012. 380(9845): p. 899-907.

70. Njelesani, J., et al., From the day they are born: A qualitative study exploring violence against children with disabilities in West Africa. BMC Public Health, 2018. 18(1): p. 153.

71. Devries, K.M., et al., Violence against primary schoolchildren with disabilities in Uganda: $A$ cross-sectional study. BMC Public Health, 2014. 14(1): p. 1017.

72. Dunne, T., et al., A Review of Effective Youth Engagement Strategies for Mental Health and Substance Use Interventions. Journal of Adolescent Health, 2016. 60(5): p. 487-512.

73. Hale, D.R., N. Fitzgerald-Yau, and R.M. Viner, A systematic review of effective interventions for reducing multiple health risk behaviors in adolescence. American Journal of Public Health, 2014. 104(5): p. e19-e41.

74. Crowley, D.M., et al., Standards of evidence for conducting and reporting economic evaluations in prevention science. Prevention Science, 2018. 19(3): p. 366-390. 
75. Araya, R., et al., School intervention to improve mental health of students in Santiago, Chile: A randomized clinical trial. JAMA Pediatrics, 2013. 167(11): p. 1004-1010. 
Table 1. Evolution of PYD models and frameworks in the United States.

\begin{tabular}{|c|c|}
\hline Model & Description \\
\hline $\begin{array}{l}\text { Developmental } \\
\text { Assets Profile } \\
\text { (Benson et al., 1998) }\end{array}$ & 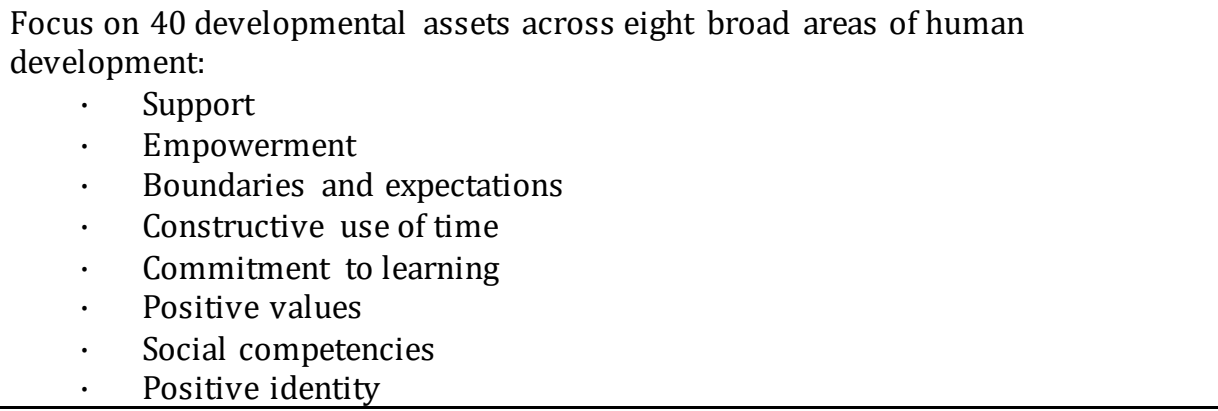 \\
\hline $\begin{array}{l}\text { Five Cs Model of PYD } \\
\text { (Lerner, 2002, 2004) }\end{array}$ & $\begin{array}{l}\text { Focus on developmental assets } \\
\text { Core constructs: } \\
\text { - Competence: Social, cognitive, behavioral, emotional, and moral } \\
\text {. } \quad \text { Confidence: Self-efficacy, self-determination, belief in the future, and } \\
\text { clear and positive identity } \\
\text {. Connection: Bonding } \\
\text {. Character: Prosocial norms, spirituality } \\
\text {. } \quad \text { Caring: Empathy and sympathy for others }\end{array}$ \\
\hline $\begin{array}{l}18 \text { Core Constructs of } \\
\text { PYD } \\
\text { (Catalano, et al., } \\
2002 \text { ) }\end{array}$ & 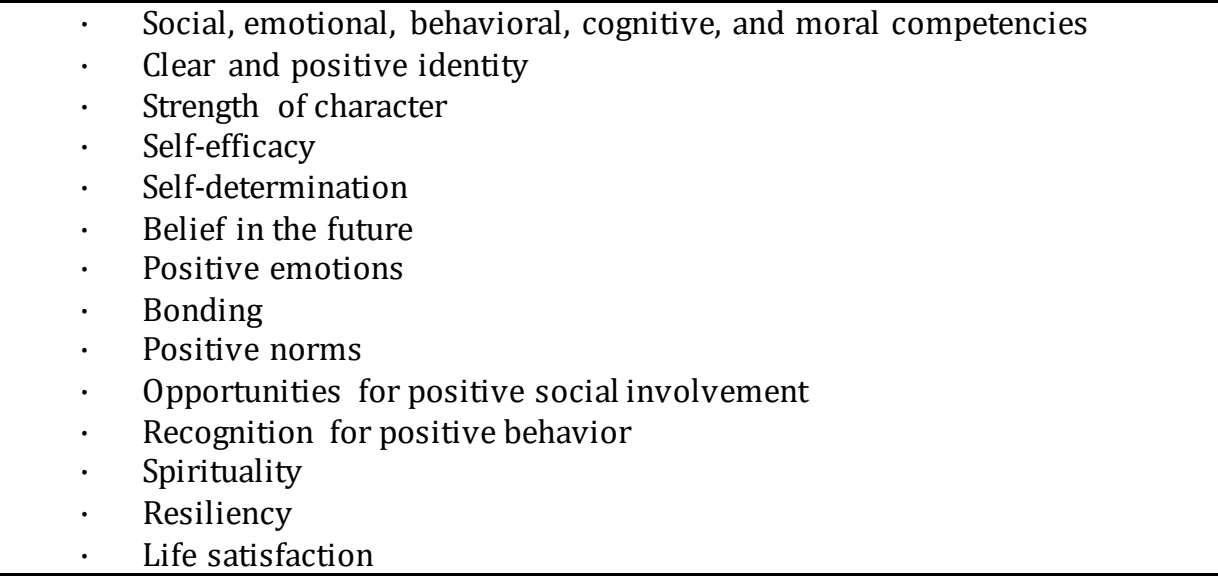 \\
\hline $\begin{array}{l}\text { Key Features of } \\
\text { Successful PYD } \\
\text { Programs, From the } \\
\text { National Research } \\
\text { Council \& the } \\
\text { Institute of Medicine } \\
\text { (Eccles \& Gootman, } \\
\text { 2002) }\end{array}$ & 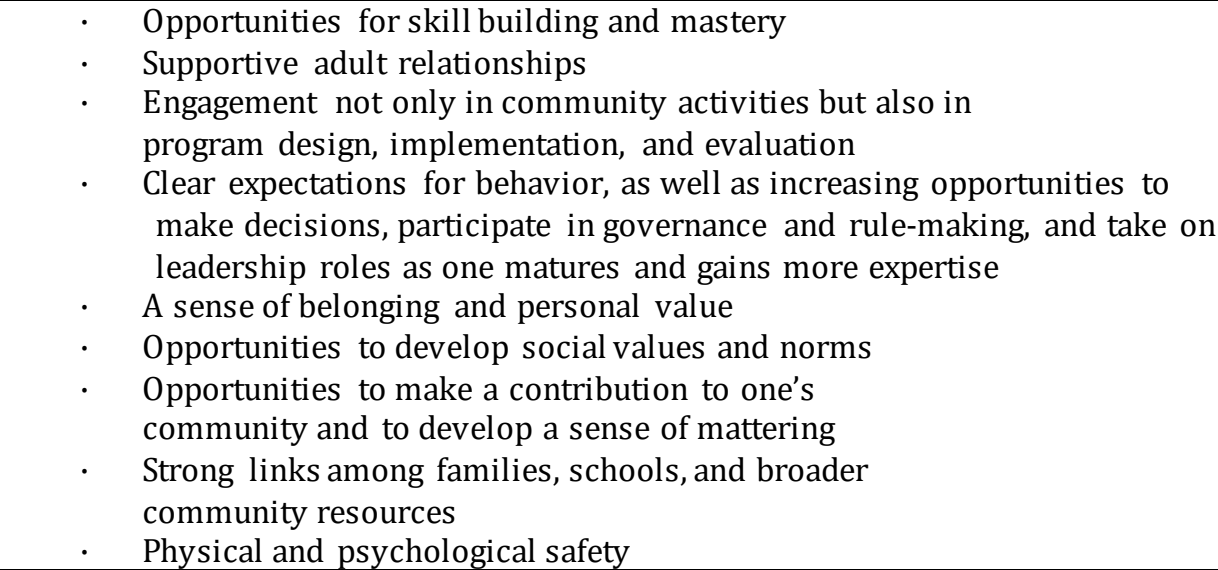 \\
\hline
\end{tabular}


Table 2. PYD constructs organized by domain.

\begin{tabular}{|c|c|}
\hline CONSTRUCT & DEFINITION \\
\hline & DOMAIN: ASSETS \\
\hline Education/ training & Exposure to formal education or training. \\
\hline $\begin{array}{l}\text { Interpersonal skills } \\
\text { (social, cognitive } \\
\text { and communication } \\
\text { skills) }\end{array}$ & $\begin{array}{l}\text { The range of skills used to communicate and interact with others, including } \\
\text { communication (verbal, nonverbal and listening), assertiveness, conflict resolution, } \\
\text { and negotiation strategies. These are skills that help to integrate feelings, thinking, } \\
\text { and actions to achieve specific social and interpersonal goals. Cognitive skills are } \\
\text { those used in academics or in decision-making and problem-solving. }\end{array}$ \\
\hline \multirow[t]{2}{*}{$\begin{array}{l}\text { Recognizing } \\
\text { emotions and self- } \\
\text { control }\end{array}$} & $\begin{array}{l}\text { The ability to identify and respond positively to feelings and emotional reactions in } \\
\text { oneself and others. The ability to delay gratification, control impulses, direct and } \\
\text { focus attention, manage emotions, and regulate one's own behaviors. }\end{array}$ \\
\hline & DOMAIN: AGENCY \\
\hline Positive identity & $\begin{array}{l}\text { Positive and coherent attitudes, beliefs, and values that one holds about oneself and } \\
\text { one's future. }\end{array}$ \\
\hline Self-efficacy & Belief in one's abilities to apply skills in real-life situations. \\
\hline $\begin{array}{l}\text { Ability to plan } \\
\text { ahead/goal-setting }\end{array}$ & $\begin{array}{l}\text { The motivation and ability to make plans and take action toward meeting a } \\
\text { personal goal. }\end{array}$ \\
\hline $\begin{array}{l}\text { Perseverance } \\
\text { (diligence) }\end{array}$ & $\begin{array}{l}\text { The capacity to sustain both effort and interest in long-term projects regardless of } \\
\text { perceived or real difficulties. Perseverance is the act of continual attempts to } \\
\text { achieve goals despite difficulties. }\end{array}$ \\
\hline \multirow[t]{2}{*}{$\begin{array}{l}\text { Positive beliefs } \\
\text { about the future }\end{array}$} & $\begin{array}{l}\text { Having hope and optimism about one's future potential, goals, options, choices, or } \\
\text { plans. }\end{array}$ \\
\hline & DOMAIN: CONTRIBUTION \\
\hline $\begin{array}{l}\text { Youth engagement } \\
\text { with civil society }\end{array}$ & $\begin{array}{l}\text { Youth participate fully in democratic and development processes, play active roles } \\
\text { in peace-building and civil society, and are less involved in youth gangs, criminal } \\
\text { networks, and insurgent organizations. }\end{array}$ \\
\hline \multirow[t]{2}{*}{$\begin{array}{l}\text { Youth engagement } \\
\text { with adults }\end{array}$} & $\begin{array}{l}\text { Meaningful youth engagement is an inclusive, intentional, mutually respectful } \\
\text { partnership between youth and adults with active participation by youth. }\end{array}$ \\
\hline & DOMAIN: ENABLING ENVIRONMENT \\
\hline Bonding & $\begin{array}{l}\text { The emotional attachment and commitment or investment made to social } \\
\text { relationships in the family, peer group, school, or community. }\end{array}$ \\
\hline $\begin{array}{l}\text { Opportunities for } \\
\text { pro-social } \\
\text { involvement }\end{array}$ & $\begin{array}{l}\text { Opportunities for positive interactions and participation in family, peer groups, } \\
\text { school, or community. }\end{array}$ \\
\hline Support & $\begin{array}{l}\text { The perception that one is cared for and supported by family, peer group, school, or } \\
\text { community. }\end{array}$ \\
\hline Pro-social norms & $\begin{array}{l}\text { Youth hold heal thy beliefs and clear standards for positive behavior and prosocial } \\
\text { engagement. }\end{array}$ \\
\hline $\begin{array}{l}\text { Value and } \\
\text { Recognition }\end{array}$ & $\begin{array}{l}\text { Youth believe that they are of value in society and that their positive contributions } \\
\text { are recognized and rewarded. This may be demonstrated through youth-friendly } \\
\text { services, policies and laws. }\end{array}$ \\
\hline Gender-responsive & $\begin{array}{l}\text { This element allows youth-identified gender issues to guide services, creating } \\
\text { through every stage of programming (site selection, staff selection, program } \\
\text { development, content, and material) an understanding of how gender affects the } \\
\text { realities of young people's lives. }\end{array}$ \\
\hline $\begin{array}{l}\text { Physical and } \\
\text { psychological safety }\end{array}$ & $\begin{array}{l}\text { Youth feel safe in their immediate environment. Physical environment is free from } \\
\text { violence, conflict, and crime. Youth feel free to express their ideas, thoughts, and } \\
\text { feelings in their environment. }\end{array}$ \\
\hline
\end{tabular}


Table 3. Positive Youth Development (PYD) programs in low- and middle-income countries with experimental or rigorous quasi-experimental evaluations

\begin{tabular}{|c|c|c|c|c|c|c|c|c|c|c|c|}
\hline Citation & $\begin{array}{l}\text { Evaluation } \\
\text { design }\end{array}$ & Sectors & Country & $\begin{array}{l}\text { Recipient } \\
\text { age }\end{array}$ & Setting & Clusters & $\begin{array}{l}\text { Sample } \\
\text { size }\end{array}$ & Brief description & Outcomes & $\begin{array}{l}\text { Follow- } \\
\text { up period }\end{array}$ & $\begin{array}{l}\text { Null or opposite } \\
\text { findings }\end{array}$ \\
\hline \multicolumn{12}{|c|}{ Child Resilience Psychosocial Structured Activities (PSSA) program } \\
\hline $\begin{array}{l}\text { Ager et al., } \\
2011 \text { [26] }\end{array}$ & $\begin{array}{l}\text { Quasi- } \\
\text { experimental }\end{array}$ & PYD & Uganda & $\begin{array}{l}7 \text { - to } 12- \\
\text { year-olds }\end{array}$ & School & 8 schools & $\begin{array}{l}T x=203 \\
C=200\end{array}$ & $\begin{array}{l}\text { Fifteen structured } \\
\text { 1-hour sessions } \\
\text { delivered in school } \\
\text { by trained teachers } \\
\text { and periodic } \\
\text { meetings with } \\
\text { parents and } \\
\text { research and } \\
\text { agency staff }\end{array}$ & $\begin{array}{l}\text { Increased child- and } \\
\text { parent-reported child } \\
\text { well-being: social } \\
\text { competence, academic } \\
\text { engagement, respectful, } \\
\text { open/honest, happy \& } \\
\text { healthy. }\end{array}$ & 12 mos. & None reported \\
\hline \multicolumn{12}{|c|}{ Life Skills Training for suicide prevention } \\
\hline $\begin{array}{l}\text { Jegannathan et } \\
\text { al., } 2014 \text { [27] }\end{array}$ & $\mathrm{RCT}$ & Mental health & Cambodia & $\begin{array}{l}\text { Secondary } \\
\text { school }\end{array}$ & School & 2 schools & $\begin{array}{c}\mathrm{Tx}=168 \\
\mathrm{C}=131\end{array}$ & $\begin{array}{l}\text { Weekly } 90-\text { minute } \\
\text { participatory } \\
\text { sessions with } \\
\text { discussions, } \\
\text { activities, and } \\
\text { home assignments }\end{array}$ & $\begin{array}{l}\text { Boys with high-risk } \\
\text { behavior improved on } \\
\text { relationship, purpose in } \\
\text { life, and life skills } \\
\text { Girls improved } \\
\text { relationships, health } \\
\text { maintenance, and life } \\
\text { skills }\end{array}$ & 6 mos. & $\begin{array}{l}\text { No effects on } \\
\text { mental health } \\
\text { overall or for low } \\
\text { risk males or any } \\
\text { females. } \\
\text { Some life skill } \\
\text { dimensions not } \\
\text { effected }\end{array}$ \\
\hline \multicolumn{12}{|c|}{ Violence prevention } \\
\hline $\begin{array}{l}\text { Ekhtiari et al., } \\
2012 \text { [28] }\end{array}$ & $\mathrm{RCT}$ & $\begin{array}{l}\text { Violence } \\
\text { prevention } \\
\text { Gender } \\
\text { equality }\end{array}$ & Iran & $\begin{array}{l}\text { High } \\
\text { school }\end{array}$ & School & 10 schools & $\begin{array}{l}T x=255 \\
C=255\end{array}$ & $\begin{array}{l}\text { Life skills training } \\
\text { specific to } \\
\text { domestic violence } \\
\text { with focus groups } \\
\text { for girls, training } \\
\text { for school } \\
\text { counselors in } \\
\text { prevention and } \\
\text { facilitating parent } \\
\text { involvement }\end{array}$ & $\begin{array}{l}\text { Reduced favorable } \\
\text { attitudes toward } \\
\text { domestic violence } \\
\text { Improved violence } \\
\text { preventive behaviors, } \\
\text { communication } \\
\text { strategies related to } \\
\text { domestic violence } \\
\text { among girls }\end{array}$ & 2 mos. & None reported \\
\hline \multicolumn{12}{|l|}{ Girls First } \\
\hline $\begin{array}{l}\text { Leventhal, et } \\
\text { al., } 2015 \text { [29] }\end{array}$ & RCT & Mental health & India & $\begin{array}{l}11-\text { to } 15- \\
\text { year-old } \\
\text { girls in } \\
\text { rural area }\end{array}$ & School & 69 schools & $\begin{array}{l}\text { Controls } \\
=706 \\
\text { Girls First } \\
\text { Resilience } \\
=1681\end{array}$ & $\begin{array}{l}\text { Weekly group soft } \\
\text { skills training, } \\
\text { work in groups to } \\
\text { design and } \\
\text { implement projects } \\
\text { for peace in their }\end{array}$ & $\begin{array}{l}\text { Improved emotional } \\
\text { resilience, self-efficacy, } \\
\text { social-emotional assets, } \\
\text { psychological well- } \\
\text { being, and social well- } \\
\text { being }\end{array}$ & 5 mos. & $\begin{array}{l}\text { No impact on } \\
\text { depression or } \\
\text { anxiety }\end{array}$ \\
\hline
\end{tabular}




\begin{tabular}{|c|c|c|c|c|c|c|c|c|c|c|c|}
\hline Citation & $\begin{array}{l}\text { Evaluation } \\
\text { design }\end{array}$ & Sectors & Country & $\begin{array}{l}\text { Recipient } \\
\text { age }\end{array}$ & Setting & Clusters & $\begin{array}{l}\text { Sample } \\
\text { size }\end{array}$ & Brief description & Outcomes & $\begin{array}{l}\text { Follow- } \\
\text { up period }\end{array}$ & $\begin{array}{l}\text { Null or opposite } \\
\text { findings }\end{array}$ \\
\hline & & & & & & & & $\begin{array}{l}\text { own lives and those } \\
\text { around them }\end{array}$ & & & \\
\hline \multicolumn{12}{|c|}{ The Life Skills and HIV/AIDS Education Program } \\
\hline $\begin{array}{l}\text { James et al., } \\
2006 \text { [30] }\end{array}$ & $\mathrm{RCT}$ & SRH/HIV & $\begin{array}{l}\text { South } \\
\text { Africa }\end{array}$ & $\begin{array}{l}12 \text { - to } 21- \\
\text { year-olds }\end{array}$ & Schools & 22 schools & $\begin{array}{l}T x=513 \\
C=628\end{array}$ & $\begin{array}{l}\text { Twenty weekly } \\
\text { lessons delivered } \\
\text { by teachers in } \\
\text { health education } \\
\text { classes }\end{array}$ & $\begin{array}{l}\text { Improved HIV } \\
\text { knowledge }\end{array}$ & $\begin{array}{l}6,10 \\
\text { mos. }\end{array}$ & $\begin{array}{l}\text { No effects on } \\
\text { condom use, sexual } \\
\text { activity, or } \\
\text { attitudes. }\end{array}$ \\
\hline \multicolumn{12}{|c|}{ Focus on Kids (adapted) School-based, peer-led HIV/AIDS prevention for children of migrant workers } \\
\hline $\begin{array}{l}\text { Li et al, } 2010 \\
\text { [31] }\end{array}$ & RCT & SRH/HIV & China & $\begin{array}{l}13 \text { - to } 15- \\
\text { year-old } \\
\text { children } \\
\text { of migrant } \\
\text { workers }\end{array}$ & School & 12 schools & $\begin{array}{l}\mathrm{Tx}=1140 \\
\mathrm{C}=1097\end{array}$ & $\begin{array}{l}\text { Eight } 90 \text {-minute } \\
\text { sessions delivered } \\
\text { by trained medical } \\
\text { students }\end{array}$ & $\begin{array}{l}\text { Increased SRH } \\
\text { knowledge, attitude, } \\
\text { and self-efficacy }\end{array}$ & 3 mos. & None reported \\
\hline \multicolumn{12}{|c|}{ The Vietnamese Focus on Kids } \\
\hline $\begin{array}{l}\text { Kaljee et al., } \\
2005 \text { [32] }\end{array}$ & $\mathrm{RCT}$ & SRH/HIV & Vietnam & $\begin{array}{l}15-\text { to } 20- \\
\text { year-old } \\
\text { rural } \\
\text { youth }\end{array}$ & $\begin{array}{l}\text { Schools } \\
\text { Community } \\
\text { outreach }\end{array}$ & $\begin{array}{l}8 \\
\text { communities }\end{array}$ & $\begin{array}{l}T x=240 \\
C=240\end{array}$ & $\begin{array}{l}\text { Participatory group } \\
\text { sessions include } \\
\text { information on } \\
\text { HIV and STIs and } \\
\text { community project } \\
\text { development and } \\
\text { delivery }\end{array}$ & $\begin{array}{l}\text { Improved HIV/AIDS } \\
\text { knowledge, self- } \\
\text { efficacy and response } \\
\text { efficacy for condom } \\
\text { use, response to cost of } \\
\text { condom use and } \\
\text { increased intention to } \\
\text { use condoms in } \\
\text { possible future sexual } \\
\text { encounters }\end{array}$ & $6 \mathrm{mos}$ & $\begin{array}{l}\text { No impact on } \\
\text { external or internal } \\
\text { rewards }\end{array}$ \\
\hline \multicolumn{12}{|c|}{ Exploring the World of Adolescents } \\
\hline $\begin{array}{l}\text { Pham et al, } \\
2012 \text { [33] }\end{array}$ & $\begin{array}{l}\text { RCT } \\
\text { with waitlist } \\
\text { control }\end{array}$ & SRH/HIV & Vietnam & $\begin{array}{l}15-\text { to } 20- \\
\text { year-olds }\end{array}$ & $\begin{array}{l}\text { Community } \\
\text { center/ } \\
\text { health clinic }\end{array}$ & NA & $\begin{array}{l}\text { Focus on } \\
\text { Kids }=317 \\
\text { Exploring } \\
\text { the World } \\
\text { of } \\
\text { Ado(EWA } \\
\text { ) } 281 \\
\text { EWA with } \\
\text { parent }= \\
273\end{array}$ & $\begin{array}{l}\text { Ten weekly 2-hour } \\
\text { sessions to build } \\
\text { knowledge and } \\
\text { skills, single-sex } \\
\text { sessions focused on } \\
\text { gender issues, } \\
\text { parent sessions } \\
\text { focused on } \\
\text { knowledge and } \\
\text { communication, } \\
\text { and workshops for } \\
\text { healthcare workers }\end{array}$ & $\begin{array}{l}\text { Increased SRH } \\
\text { knowledge and } \\
\text { improved attitudes }\end{array}$ & $\begin{array}{l}3,6,12 \\
\text { mos. }\end{array}$ & $\begin{array}{l}\text { Opposite findings } \\
\text { for some measures } \\
\text { of knowledge and } \\
\text { attitudes for all } \\
\text { groups at various } \\
\text { follow-up periods. }\end{array}$ \\
\hline
\end{tabular}




\begin{tabular}{|c|c|c|c|c|c|c|c|c|c|c|c|}
\hline Citation & $\begin{array}{l}\text { Evaluation } \\
\text { design }\end{array}$ & Sectors & Country & $\begin{array}{l}\text { Recipient } \\
\text { age }\end{array}$ & Setting & Clusters & $\begin{array}{l}\text { Sample } \\
\text { size }\end{array}$ & Brief description & Outcomes & $\begin{array}{l}\text { Follow- } \\
\text { up period }\end{array}$ & $\begin{array}{l}\text { Null or opposite } \\
\text { findings }\end{array}$ \\
\hline & & & & & & & & $\begin{array}{l}\text { to improve youth- } \\
\text { friendly services }\end{array}$ & & & \\
\hline \multicolumn{12}{|c|}{ Peer intervention on the knowledge and attitudes about HIV/AIDS in adolescents } \\
\hline $\begin{array}{l}\text { Aramburú et } \\
\text { al., } 2012 \text { [34] }\end{array}$ & $\mathrm{RCT}$ & SRH/HIV & Panama & $\begin{array}{l}\text { High } \\
\text { school } \\
\text { students } \\
\text { (mean age } \\
\text { 15) }\end{array}$ & School & 4 schools & $\begin{aligned} \mathrm{Tx} & =354 \\
\mathrm{C} & =305\end{aligned}$ & $\begin{array}{l}\text { Professionally } \\
\text { trained peer-leaders } \\
\text { of activities and } \\
\text { discussions to } \\
\text { identify and } \\
\text { address risk and } \\
\text { protective factors, } \\
\text { theatrical } \\
\text { presentations and } \\
\text { videos }\end{array}$ & $\begin{array}{l}\text { Improved knowledge of } \\
\text { risks and attitude } \\
\text { toward knowing the } \\
\text { HIV status of their } \\
\text { sexual partner } \\
\text { Reduced discrimination } \\
\text { toward people with } \\
\text { HIV } \\
\text { Reduced reported } \\
\text { embarrassment about } \\
\text { purchasing a condom }\end{array}$ & 3 mos. & None reported \\
\hline \multicolumn{12}{|l|}{ Parivartan } \\
\hline $\begin{array}{l}\text { Miller et al., } \\
2014 \text { [35] }\end{array}$ & $\mathrm{RCT}$ & $\begin{array}{l}\text { Violence } \\
\text { prevention } \\
\text { Gender } \\
\text { equality }\end{array}$ & India & $\begin{array}{l}10 \text { - to } 16- \\
\text { year-old } \\
\text { males in } \\
\text { cricket } \\
\text { league }\end{array}$ & $\begin{array}{l}\text { Cricket } \\
\text { league team } \\
\text { practice }\end{array}$ & & $\begin{array}{l}\mathrm{Tx}=168 \\
\mathrm{C}=141\end{array}$ & $\begin{array}{l}\text { Structured training } \\
\text { of cricket coaches } \\
\text { to use topic cards } \\
\text { to engage young } \\
\text { men in reflections } \\
\text { on gender roles and } \\
\text { discourage } \\
\text { disrespectful } \\
\text { behavior toward } \\
\text { women }\end{array}$ & $\begin{array}{l}\text { Improved gender norms } \\
\text { and attitudes }\end{array}$ & 12 mos. & $\begin{array}{l}\text { No effects on } \\
\text { bystander behavior } \\
\text { or perpetration of } \\
\text { violence }\end{array}$ \\
\hline \multicolumn{12}{|c|}{ Let Us Protect Our Future } \\
\hline $\begin{array}{l}\text { O'Leary et al., } \\
2012 \text { [38] [39] }\end{array}$ & RCT & SRH/HIV & $\begin{array}{l}\text { South } \\
\text { Africa }\end{array}$ & $\begin{array}{l}\text { grade } 6 \\
\text { students }\end{array}$ & School & 18 schools & $\begin{array}{l}T x=562 \\
C=495\end{array}$ & $\begin{array}{l}\text { Six 2-hour mixed- } \\
\text { sex sessions led by } \\
\text { trained facilitators, } \\
\text { some sex-specific } \\
\text { modules to address } \\
\text { gender norms, and } \\
\text { homework } \\
\text { assignments with } \\
\text { parents }\end{array}$ & $\begin{array}{l}\text { Reduced risky sexual } \\
\text { behavior } \\
\text { Increased self-efficacy } \\
\text { and parental } \\
\text { engagement }\end{array}$ & $\begin{array}{l}3,6,12 \\
\text { mos. }\end{array}$ & None reported \\
\hline \multicolumn{12}{|l|}{ Wake Up } \\
\hline $\begin{array}{l}\text { Heeren et al., } \\
2013 \text { [41] }\end{array}$ & RCT & SRH/HIV & $\begin{array}{l}\text { South } \\
\text { Africa }\end{array}$ & $\begin{array}{l}19-\text { to } 24- \\
\text { year-olds }\end{array}$ & $\begin{array}{l}\text { University } \\
\text { campus }\end{array}$ & & $\begin{array}{l}\mathrm{Tx}=91 \\
\mathrm{C}=85\end{array}$ & $\begin{array}{l}\text { Eight } 90 \text {-minute } \\
\text { sessions over } 4 \\
\text { weeks in mixed-sex }\end{array}$ & $\begin{array}{l}\text { Reduced unprotected } \\
\text { vaginal intercourse } \\
\text { Increased condom use }\end{array}$ & $\begin{array}{l}6,12 \\
\text { mos. }\end{array}$ & $\begin{array}{l}\text { No effect on } \\
\text { multiple sexual } \\
\text { partners }\end{array}$ \\
\hline
\end{tabular}




\begin{tabular}{|c|c|c|c|c|c|c|c|c|c|c|}
\hline $\begin{array}{l}\text { Evaluation } \\
\text { design }\end{array}$ & Sectors & Country & $\begin{array}{l}\text { Recipient } \\
\text { age }\end{array}$ & Setting & Clusters & $\begin{array}{l}\text { Sample } \\
\text { size }\end{array}$ & Brief description & Outcomes & $\begin{array}{l}\text { Follow- } \\
\text { up period }\end{array}$ & $\begin{array}{l}\text { Null or opposite } \\
\text { findings }\end{array}$ \\
\hline & & & & & & & $\begin{array}{l}\text { groups lead by } \\
\text { graduate students }\end{array}$ & $\begin{array}{l}\text { Improved self-efficacy, } \\
\text { SRH knowledge and } \\
\text { attitudes } \\
\text { More effective for non- } \\
\text { South African students }\end{array}$ & & \\
\hline \multicolumn{11}{|c|}{ Community-based ASRH intervention } \\
\hline $\begin{array}{l}\text { Aninanya et al., } \quad \text { RCT } \\
2015 \text { [37] }\end{array}$ & $\begin{array}{l}\text { SRH/HIV } \\
\text { Substance use } \\
\text { prevention }\end{array}$ & Ghana & $\begin{array}{l}10-\text { to } 17- \\
\text { year-olds }\end{array}$ & $\begin{array}{l}\text { School } \\
\text { Health } \\
\text { clinic } \\
\text { Community } \\
\text { outreach }\end{array}$ & $\begin{array}{l}26 \\
\text { communities }\end{array}$ & $\begin{array}{l}\mathrm{Tx}=1288 \\
\mathrm{C}=1376\end{array}$ & $\begin{array}{l}\text { Stakeholder } \\
\text { meetings, health } \\
\text { worker training, in- } \\
\text { school curriculum, } \\
\text { and peer outreach } \\
\text { to youth not } \\
\text { attending school }\end{array}$ & $\begin{array}{l}\text { Increased SRH } \\
\text { knowledge and attitude, } \\
\text { satisfaction with health } \\
\text { services, STI } \\
\text { management, and usage } \\
\text { of pregnancy and birth } \\
\text { related health services. }\end{array}$ & 3 years & $\begin{array}{l}\text { No effect on HIV } \\
\text { testing and } \\
\text { counselling. }\end{array}$ \\
\hline \multicolumn{11}{|c|}{ Peer-led education program for HIV/AIDS } \\
\hline $\begin{array}{l}\text { Ibrahim et al., } \quad \text { RCT } \\
2012 \text { [42] }\end{array}$ & SRH/HIV & Malaysia & $\begin{array}{l}17-\text { to } 24- \\
\text { year-old } \\
\text { college } \\
\text { students }\end{array}$ & University & & $\begin{array}{l}\mathrm{Tx}=137 \\
\mathrm{C}=144\end{array}$ & $\begin{array}{l}\text { Eight peer-to-peer } \\
\text { workshop sessions } \\
\text { focused on HIV } \\
\text { prevention skills } \\
\text { and behaviors }\end{array}$ & $\begin{array}{l}\text { Reduced HIV substance } \\
\text { use risk behavior } \\
\text { Improved SRH } \\
\text { knowledge and attitude }\end{array}$ & 3 mos. & None reported \\
\hline \multicolumn{11}{|c|}{ Responsible, Engaged, and Loving Fathers (REAL) } \\
\hline $\begin{array}{l}\text { Ashburn et al., } \quad \text { RCT } \\
2017[36]\end{array}$ & $\begin{array}{l}\text { Violence } \\
\text { prevention }\end{array}$ & Uganda & $\begin{array}{l}16-\text { to } 25- \\
\text { year-old } \\
\text { fathers of } \\
1-\text { to } 3 \text { - } \\
\text { year-olds }\end{array}$ & $\begin{array}{l}\text { Community } \\
\text { orgs }\end{array}$ & NA & $\begin{array}{l}\mathrm{Tx}=232 \\
\mathrm{C}=169\end{array}$ & $\begin{array}{l}\text { Mentoring of } \\
\text { young fathers and } \\
\text { poster campaign } \\
\text { focused on } \\
\text { nonviolent } \\
\text { parenting skills and } \\
\text { norms }\end{array}$ & $\begin{array}{l}\text { Reduced intimate } \\
\text { partner violence and } \\
\text { use of physical } \\
\text { punishment. Increased } \\
\text { attitudes against } \\
\text { physical punishment } \\
\text { and confidence in } \\
\text { ability to use nonviolent } \\
\text { discipline } \\
\text { Improvement in } \\
\text { communication skills, } \\
\text { more time with the } \\
\text { child, and positive } \\
\text { parenting }\end{array}$ & $\begin{array}{l}10 \\
18-22 \\
\text { mos. }\end{array}$ & $\begin{array}{l}\text { No effect on } \\
\text { traditional gender } \\
\text { norms }\end{array}$ \\
\hline
\end{tabular}




\begin{tabular}{|c|c|c|c|c|c|c|c|c|c|c|c|}
\hline Citation & $\begin{array}{l}\text { Evaluation } \\
\text { design }\end{array}$ & Sectors & Country & $\begin{array}{l}\text { Recipient } \\
\text { age }\end{array}$ & Setting & Clusters & $\begin{array}{l}\text { Sample } \\
\text { size }\end{array}$ & Brief description & Outcomes & $\begin{array}{l}\text { Follow- } \\
\text { up period }\end{array}$ & $\begin{array}{l}\text { Null or opposite } \\
\text { findings }\end{array}$ \\
\hline \multicolumn{12}{|c|}{ Life Skills for mental health promotion } \\
\hline $\begin{array}{l}\text { Srikala and } \\
\text { Kishore, } 2010 \\
{[44]}\end{array}$ & $\mathrm{RCT}$ & Mental health & India & $\begin{array}{l}14-\text { to } 16- \\
\text { year-olds }\end{array}$ & Schools & NA & $\begin{array}{l}\mathrm{Tx}=605 \\
C=423\end{array}$ & $\begin{array}{l}\text { Life skills training } \\
\text { in school }\end{array}$ & $\begin{array}{l}\text { Improved self-esteem, } \\
\text { perceived coping, } \\
\text { adjustment in school } \\
\text { and with teachers, and } \\
\text { pro-social behavior }\end{array}$ & 12 mos. & $\begin{array}{l}\text { No impact on } \\
\text { conduct problems, } \\
\text { emotion problems, } \\
\text { hyperactivity, } \\
\text { adjustment with } \\
\text { parents and peers }\end{array}$ \\
\hline \multicolumn{12}{|c|}{ STEP II for HIV and alcohol use prevention } \\
\hline $\begin{array}{l}\text { Chhabra et al., } \\
2010 \text { [45] }\end{array}$ & $\mathrm{RCT}$ & $\begin{array}{l}\text { SRH/HIV } \\
\text { Substance use } \\
\text { prevention }\end{array}$ & India & $\begin{array}{l}\text { 13- to 16- } \\
\text { year-old } \\
\text { rural } \\
\text { youth }\end{array}$ & $\begin{array}{l}\text { School } \\
\text { Community } \\
\text { orgs }\end{array}$ & 23 schools & $\begin{array}{l}\mathrm{Tx}=630 \\
\mathrm{C}=624\end{array}$ & $\begin{array}{l}\text { Classroom } \\
\text { curriculum on } \\
\text { HIV/AIDS and } \\
\text { alcohol abuse, soft } \\
\text { skill training and } \\
\text { development of } \\
\text { individual values }\end{array}$ & $\begin{array}{l}\text { Improved } \\
\text { communication skills } \\
\text { among females only } \\
\text { Reductions in intend to } \\
\text { use alcohol, tobacco, or } \\
\text { other drugs. }\end{array}$ & 10 weeks & $\begin{array}{l}\text { No overall } \\
\text { significant effects } \\
\text { or effects for Males } \\
\text { on Knowledge, } \\
\text { efficacy, risk or } \\
\text { confidence. }\end{array}$ \\
\hline \multicolumn{12}{|l|}{ keepin' it REAL } \\
\hline $\begin{array}{l}\text { Marsiglia et al., } \\
2014 \text { [46] } \\
\text { Marsiglia et al., } \\
2015 \text { [47] }\end{array}$ & $\mathrm{RCT}$ & Substance use & Mexico & $\begin{array}{l}\text { Early } \\
\text { adolescent } \\
\text { urban } \\
\text { youth }\end{array}$ & School & 2 schools & $\begin{array}{l}T x=206 \\
C=225\end{array}$ & $\begin{array}{l}\text { Teacher-led } \\
\text { curriculum focused } \\
\text { on refusal skills } \\
\text { and avoidance } \\
\text { strategies }\end{array}$ & $\begin{array}{l}\text { Reduced amount and } \\
\text { frequency of alcohol } \\
\text { among females }\end{array}$ & 8 mos. & $\begin{array}{l}\text { No effect on } \\
\text { cigarette use } \\
\text { No effect on } \\
\text { alcohol for males, }\end{array}$ \\
\hline \multicolumn{12}{|c|}{ Romanian peer-led smoking prevention } \\
\hline $\begin{array}{l}\text { Lotrean et al., } \\
2010 \text { [48] }\end{array}$ & $\mathrm{RCT}$ & Substance use & Romania & $\begin{array}{l}13-\text { to } 14- \\
\text { year-olds }\end{array}$ & School & 20 schools & $\begin{array}{l}\mathrm{Tx}=523 \\
C=548\end{array}$ & $\begin{array}{l}\text { Five } 45 \text {-minute } \\
\text { sessions using a } \\
\text { peer-led video } \\
\text { strategy }\end{array}$ & $\begin{array}{l}\text { Reduced smoking } \\
\text { onset, positive attitudes } \\
\text { toward smoking and } \\
\text { intentions to smoke } \\
\text { Improved social self- } \\
\text { efficacy }\end{array}$ & 9 mos. & $\begin{array}{l}\text { No effect on some } \\
\text { attitude measures } \\
\text { and emotional or } \\
\text { situational self- } \\
\text { efficacy }\end{array}$ \\
\hline \multicolumn{12}{|l|}{ Questscope } \\
\hline $\begin{array}{l}\text { Morton, et al., } \\
2012 \text { [43] }\end{array}$ & $\begin{array}{l}\text { RCT } \\
\text { with waitlist } \\
\text { comparison }\end{array}$ & $\begin{array}{l}\text { PYD } \\
\text { Delinquency }\end{array}$ & Jordan & $\begin{array}{l}13-\text { to } 21- \\
\text { year-olds }\end{array}$ & $\begin{array}{l}\text { Single-sex } \\
\text { groups in } \\
\text { community } \\
\text { orgs and }\end{array}$ & & $\begin{array}{l}\mathrm{Tx}=67 \\
\mathrm{C}=60 \\
85 \% \text { male }\end{array}$ & $\begin{array}{l}\text { Education support } \\
\text { through group } \\
\text { sessions plus } \\
\text { recreational } \\
\text { activities }\end{array}$ & $\begin{array}{l}\text { Reduced conduct } \\
\text { problems }\end{array}$ & 4 mos. & $\begin{array}{l}\text { No effects on self- } \\
\text { efficacy, social } \\
\text { skills, social } \\
\text { supports, overall }\end{array}$ \\
\hline
\end{tabular}




\begin{tabular}{|c|c|c|c|c|c|c|c|c|c|c|c|}
\hline Citation & $\begin{array}{l}\text { Evaluation } \\
\text { design }\end{array}$ & Sectors & Country & $\begin{array}{l}\text { Recipient } \\
\text { age }\end{array}$ & Setting & Clusters & $\begin{array}{l}\text { Sample } \\
\text { size }\end{array}$ & Brief description & Outcomes & $\begin{array}{l}\text { Follow- } \\
\text { up period }\end{array}$ & $\begin{array}{l}\text { Null or opposite } \\
\text { findings }\end{array}$ \\
\hline & & & & & $\begin{array}{l}\text { school } \\
\text { buildings }\end{array}$ & & & & & & $\begin{array}{l}\text { difficulties, or adult } \\
\text { connectedness }\end{array}$ \\
\hline \multicolumn{12}{|c|}{ Stepping Stones } \\
\hline $\begin{array}{l}\text { Jewkes et al., } \\
2008 \text { [52] }\end{array}$ & $\mathrm{RCT}$ & $\begin{array}{l}\text { SRH/HIV } \\
\text { Employment } \\
\text { Violence } \\
\text { prevention } \\
\text { Gender } \\
\text { equality }\end{array}$ & $\begin{array}{l}\text { South } \\
\text { Africa }\end{array}$ & $\begin{array}{l}16-\text { to } 20- \\
\text { year-olds }\end{array}$ & $\begin{array}{l}\text { Community } \\
\text { orgs }\end{array}$ & $\begin{array}{l}70 \text { villages/ } \\
\text { townships }\end{array}$ & $\begin{array}{l}T x=1409 \\
C=1367\end{array}$ & $\begin{array}{l}\text { Thirteen 3-hour } \\
\text { sessions in single- } \\
\text { sex groups led by } \\
\text { trained same-sex } \\
\text { and age facilitators, } \\
\text { three combined } \\
\text { mixed-sex group } \\
\text { sessions, and one } \\
\text { community } \\
\text { meeting }\end{array}$ & $\begin{array}{l}\text { Reduced HSV-2 } \\
\text { prevalence } \\
\text { Reduced self-reported } \\
\text { intimate partner } \\
\text { violence, problem } \\
\text { drinking and } \\
\text { transactional sex among } \\
\text { men }\end{array}$ & $\begin{array}{l}12,24 \\
\text { mos. }\end{array}$ & $\begin{array}{l}\text { No impact on } \\
\text { incidence of HIV } \\
\text { No effect on risk } \\
\text { behavior or risk } \\
\text { exposure for } \\
\text { women }\end{array}$ \\
\hline \multicolumn{12}{|c|}{ Creating Futures/Stepping Stones } \\
\hline $\begin{array}{l}\text { Jewkes et al., } \\
2014 \text { [54] }\end{array}$ & $\begin{array}{l}\text { Quasi- } \\
\text { experimental } \\
\text { interrupted } \\
\text { time series }\end{array}$ & $\begin{array}{l}\text { SRH/HIV } \\
\text { Employment }\end{array}$ & $\begin{array}{l}\text { South } \\
\text { Africa }\end{array}$ & $\begin{array}{l}\text { 18- to 34- } \\
\text { year olds } \\
\text { (most } \\
\text { under } 30 \\
\text { years old) }\end{array}$ & $\begin{array}{l}\text { Community } \\
\text { outreach }\end{array}$ & & 232 & $\begin{array}{l}\text { Stepping Stones } \\
\text { program followed } \\
\text { by } 113 \text {-hour } \\
\text { sessions helping } \\
\text { participants find } \\
\text { work, build } \\
\text { businesses }\end{array}$ & $\begin{array}{l}\text { Increased earnings, } \\
\text { improved gender } \\
\text { attitudes } \\
\text { Decreased depression, } \\
\text { suicidal thoughts, and } \\
\text { relationship control } \\
\text { behaviors among men } \\
\text { Reduced physical } \\
\text { and/or sexual abuse } \\
\text { reported among women }\end{array}$ & $\begin{array}{l}7,14 \\
\text { mos. }\end{array}$ & $\begin{array}{l}\text { No impact on } \\
\text { several other } \\
\text { economic and } \\
\text { relationship } \\
\text { indicators }\end{array}$ \\
\hline \multicolumn{12}{|c|}{ Street Smart plus Vocational Training } \\
\hline $\begin{array}{l}\text { Rotheram- } \\
\text { Borus et al., } \\
2012 \text { [55] }\end{array}$ & $\begin{array}{l}\text { RCT } \\
\text { with waitlist } \\
\text { control }\end{array}$ & $\begin{array}{l}\text { SRH/HIV } \\
\text { Employment }\end{array}$ & Uganda & $\begin{array}{l}13 \text { - to } 23 \text { - } \\
\text { year-olds }\end{array}$ & $\begin{array}{l}\text { Community } \\
\text { orgs }\end{array}$ & NA & $\begin{array}{l}\mathrm{Tx}=50 \\
\mathrm{C}=50\end{array}$ & $\begin{array}{l}\text { Classes daily for } 4- \\
8 \text { hours, } 5 \text { days/ } \\
\text { week for } 10 \text { weeks, } \\
\text { apprenticeships } \\
\text { with local artisans } \\
\text { Artisans received a } \\
\text { 5-day training on } \\
\text { HIV and how to } \\
\text { supervise youth }\end{array}$ & $\begin{array}{l}\text { Reduced delinquent } \\
\text { behaviors and improved } \\
\text { employment, quality of } \\
\text { life, and social support }\end{array}$ & $\begin{array}{l}4,24 \\
\text { mos. }\end{array}$ & $\begin{array}{l}\text { No effect on sexual } \\
\text { risk behavior }\end{array}$ \\
\hline \multicolumn{12}{|c|}{ Teaching Recovery } \\
\hline $\begin{array}{l}\text { Qouta et al., } \\
2012 \text { [56] }\end{array}$ & $\mathrm{RCT}$ & Mental health & Palestine & $\begin{array}{l}10 \text { - to } 13- \\
\text { year-old } \\
\text { war- }\end{array}$ & School & NA & $\begin{array}{l}\mathrm{Tx}=242 \\
\mathrm{C}=240\end{array}$ & $\begin{array}{l}\text { CBT methods, } \\
\text { coping skills } \\
\text { training, creative }\end{array}$ & $\begin{array}{l}\text { Reduced PTSD } \\
\text { diagnoses }\end{array}$ & $6 \mathrm{mos}$ & $\begin{array}{l}\text { No effects on } \\
\text { overall symptom } \\
\text { level or measures }\end{array}$ \\
\hline
\end{tabular}




\begin{tabular}{|c|c|c|c|c|c|c|c|c|c|c|c|}
\hline Citation & $\begin{array}{l}\text { Evaluation } \\
\text { design }\end{array}$ & Sectors & Country & $\begin{array}{l}\text { Recipient } \\
\text { age }\end{array}$ & Setting & Clusters & $\begin{array}{l}\text { Sample } \\
\text { size }\end{array}$ & Brief description & Outcomes & $\begin{array}{l}\text { Follow- } \\
\text { up period }\end{array}$ & $\begin{array}{l}\text { Null or opposite } \\
\text { findings }\end{array}$ \\
\hline & & & & $\begin{array}{l}\text { affected } \\
\text { youth }\end{array}$ & & & & $\begin{array}{l}\text { expression, } \\
\text { homework } \\
\text { involving parents }\end{array}$ & & & $\begin{array}{l}\text { of psychological } \\
\text { distress, except for } \\
\text { girls with low risk. }\end{array}$ \\
\hline \multicolumn{12}{|c|}{ Program for war-affected young people } \\
\hline $\begin{array}{l}\text { O'Callaghan et } \\
\text { al., } 2014 \text { [57] }\end{array}$ & $\mathrm{RCT}$ & Mental health & $\begin{array}{l}\text { Democratic } \\
\text { Republic of } \\
\text { Congo }\end{array}$ & $\begin{array}{l}7 \text { - to } 18- \\
\text { year-olds } \\
\text { who have } \\
\text { been } \\
\text { abducted } \\
\text { in war- } \\
\text { torn areas }\end{array}$ & $\begin{array}{l}\text { Community } \\
\text { orgs }\end{array}$ & NA & $\begin{array}{l}\text { Tx }=79 \\
C=80\end{array}$ & $\begin{array}{l}\text { Eight 2-hour } \\
\text { sessions for youth } \\
\text { and their caregiver } \\
\text { led by trained } \\
\text { female facilitators } \\
\text { offering life skills, } \\
\text { Mobile Cinema } \\
\text { clips, and } \\
\text { relaxation } \\
\text { techniques }\end{array}$ & $\begin{array}{l}\text { Improved PTSD } \\
\text { symptoms }\end{array}$ & 3 mos. & $\begin{array}{l}\text { No effects on } \\
\text { conduct, } \\
\text { depression, } \\
\text { anxiety, or } \\
\text { prosocial attitudes }\end{array}$ \\
\hline \multicolumn{12}{|l|}{ Yes Youth Can } \\
\hline $\begin{array}{l}\text { NORAC, } 2014 \\
{[58]}\end{array}$ & $\begin{array}{l}\text { Quasi- } \\
\text { experimental }\end{array}$ & $\begin{array}{l}\text { SRH/HIV } \\
\text { Employment }\end{array}$ & Kenya & $\begin{array}{l}18 \text { - to } 35- \\
\text { year-olds }\end{array}$ & $\begin{array}{l}\text { School } \\
\text { Community } \\
\text { orgs }\end{array}$ & & $\begin{array}{c}T x=6370 \\
C=3216\end{array}$ & $\begin{array}{l}\text { Infrastructure for } \\
\text { youth to form } \\
\text { groups and work } \\
\text { toward group- } \\
\text { determined goals, } \\
\text { training (e.g., life } \\
\text { skills), funding for } \\
\text { projects, and } \\
\text { support for county } \\
\text { and national } \\
\text { organizational } \\
\text { structure }\end{array}$ & $\begin{array}{l}\text { Increased asset } \\
\text { ownership, political } \\
\text { empowerment, self- } \\
\text { efficacy, and attitudes } \\
\text { about community } \\
\text { supportiveness }\end{array}$ & 18 mos. & $\begin{array}{l}\text { No impact on } \\
\text { income or some } \\
\text { political } \\
\text { empowerment } \\
\text { items or attitudes } \\
\text { toward other ethnic } \\
\text { groups }\end{array}$ \\
\hline \multicolumn{12}{|l|}{ Akazi Kanoze } \\
\hline $\begin{array}{l}\text { Alcid et al., } \\
2014 \text { [59] }\end{array}$ & $\mathrm{RCT}$ & Employment & Rwanda & $\begin{array}{l}14-\text { to } 35- \\
\text { year-olds: } \\
\text { over } 95 \% \\
15 \text { - to } 29- \\
\text { years-old }\end{array}$ & $\begin{array}{l}\text { Community } \\
\text { orgs }\end{array}$ & NA & $\begin{array}{l}T x=300 \\
C=300\end{array}$ & $\begin{array}{l}\text { Work readiness } \\
\text { curriculum } \\
\text { including soft } \\
\text { skills, general } \\
\text { educational needs, } \\
\text { and specialized } \\
\text { training with } \\
\text { workforce linkages }\end{array}$ & $\begin{array}{l}\text { Increased number of } \\
\text { employed youth and } \\
\text { improved ability to } \\
\text { apply for a job, develop } \\
\text { a business plan, } \\
\text { understand marketing } \\
\text { techniques, likelihood } \\
\text { of having savings and a } \\
\text { mentor }\end{array}$ & 10 mos. & $\begin{array}{l}\text { Intervention only } \\
\text { effective in } 1 \text { of } 2 \\
\text { districts. Most } \\
\text { impact on female } \\
\text { and lower educated } \\
\text { youth. } \\
\text { NO impact on } \\
\text { business startup or } \\
\text { work improvement } \\
\text { skills }\end{array}$ \\
\hline
\end{tabular}




\begin{tabular}{|c|c|c|c|c|c|c|c|c|c|c|c|}
\hline Citation & $\begin{array}{l}\text { Evaluation } \\
\text { design }\end{array}$ & Sectors & Country & $\begin{array}{l}\text { Recipient } \\
\text { age }\end{array}$ & Setting & Clusters & $\begin{array}{l}\text { Sample } \\
\text { size }\end{array}$ & Brief description & Outcomes & $\begin{array}{l}\text { Follow- } \\
\text { up period }\end{array}$ & $\begin{array}{l}\text { Null or opposite } \\
\text { findings }\end{array}$ \\
\hline \multicolumn{12}{|l|}{ Pro Joven } \\
\hline $\begin{array}{l}\text { Diaz and Rosas, } \\
2016 \text { [60] }\end{array}$ & $\begin{array}{l}\text { Quasi- } \\
\text { experimental }\end{array}$ & Employment & Peru & $14-26$ & $\begin{array}{l}\text { Community } \\
\text { orgs } \\
\text { Health } \\
\text { clinics } \\
\text { Home/ } \\
\text { homework } \\
\text { w/ parents }\end{array}$ & NA & $\begin{array}{l}\mathrm{Tx}=2378 \\
\mathrm{C}=546\end{array}$ & $\begin{array}{l}\text { Individual } \\
\text { vocational training } \\
\text { and internships }\end{array}$ & $\begin{array}{l}\text { Increased the } \\
\text { probability of } \\
\text { employment, paid } \\
\text { employment, having a } \\
\text { job with health } \\
\text { insurance or a pension } \\
\text { Improved earnings } \\
\text { Primarily effective for } \\
\text { females and youths } \\
\text { between } 14 \text { and } 18 \\
\text { years of age }\end{array}$ & $\begin{array}{l}6,12,18 \\
\text { mos. }\end{array}$ & None reported \\
\hline \multicolumn{12}{|c|}{ Juventud y Empleo } \\
\hline $\begin{array}{l}\text { Ibarraran et al., } \\
2014 \text { [61] } \\
\text { Ibarraran et al., } \\
2015 \text { [49] }\end{array}$ & $\mathrm{RCT}$ & $\begin{array}{l}\text { Employment } \\
\text { SRH/HIV }\end{array}$ & $\begin{array}{l}\text { Dominican } \\
\text { Republic }\end{array}$ & $\begin{array}{l}\text { 16- to } 29- \\
\text { year-olds }\end{array}$ & $\begin{array}{l}\text { Workplace } \\
\text { and training } \\
\text { centers }\end{array}$ & & $\begin{array}{l}\mathrm{Tx}=3250 \\
\mathrm{C}=1750\end{array}$ & $\begin{array}{l}\text { Life skills training } \\
\text { and vocational } \\
\text { training and } \\
\text { internships }\end{array}$ & $\begin{array}{l}\text { Increased employment } \\
\text { with written contract, } \\
\text { monthly earnings, } \\
\text { educational } \\
\text { expectations, and } \\
\text { perception of health } \\
\text { Reduced pregnancy } \\
\text { and duration of } \\
\text { unemployment } \\
\text { Increased employed } \\
\text { with health insurance } \\
\text { among men }\end{array}$ & 2,6 years & $\begin{array}{l}\text { No impact on } \\
\text { earnings, overall } \\
\text { employment. } \\
\text { Long term impacts } \\
\text { limited to formal } \\
\text { employment and } \\
\text { stronger for men. }\end{array}$ \\
\hline \multicolumn{12}{|c|}{ Supporting Adolescent Orphan Girls to Stay in School as HIV risk prevention } \\
\hline $\begin{array}{l}\text { Hallfors et al., } \\
2011 \text { [62] } \\
\text { Hallfors et al., } \\
2015 \text { [50] }\end{array}$ & $\mathrm{RCT}$ & $\begin{array}{l}\text { SRH/HIV } \\
\text { education }\end{array}$ & Zimbabwe & $\begin{array}{l}10 \text { - to } 16- \\
\text { year-old } \\
\text { orphan } \\
\text { girls }\end{array}$ & Schools & 26 schools & $\begin{array}{l}\mathrm{Tx}=184 \\
\mathrm{C}=145\end{array}$ & $\begin{array}{l}\text { Material and } \\
\text { mentoring support } \\
\text { for orphan girls to } \\
\text { keep them in } \\
\text { school }\end{array}$ & $\begin{array}{l}\text { Improved educational } \\
\text { behavior outcomes, } \\
\text { SRH knowledge and } \\
\text { attitudes, and gender } \\
\text { norms } \\
\text { After } 5 \text { years: Reduced } \\
\text { the likelihood of } \\
\text { marriage, improved } \\
\text { school retention and } \\
\text { food security }\end{array}$ & 5 years & $\begin{array}{l}\text { No effects on HIV } \\
\text { or HSV-2 }\end{array}$ \\
\hline \multicolumn{12}{|l|}{ SHAZ } \\
\hline $\begin{array}{l}\text { Dunbar et al., } \\
2014 \text { [63] }\end{array}$ & RCT & SRH/HIV & Zimbabwe & $\begin{array}{l}17-\text { to } 19- \\
\text { year-old }\end{array}$ & $\begin{array}{l}\text { Community } \\
\text { orgs }\end{array}$ & & $\begin{array}{l}T x=158 \\
C=157\end{array}$ & $\begin{array}{l}\text { Life-skills and } \\
\text { health education, }\end{array}$ & $\begin{array}{l}\text { Increased food security, } \\
\text { having own income }\end{array}$ & 24 mos. & No effect on \\
\hline
\end{tabular}




\begin{tabular}{|c|c|c|c|c|c|c|c|c|c|c|c|}
\hline Citation & $\begin{array}{l}\text { Evaluation } \\
\text { design }\end{array}$ & Sectors & Country & $\begin{array}{l}\text { Recipient } \\
\text { age }\end{array}$ & Setting & Clusters & $\begin{array}{l}\text { Sample } \\
\text { size }\end{array}$ & Brief description & Outcomes & $\begin{array}{l}\text { Follow- } \\
\text { up period }\end{array}$ & $\begin{array}{l}\text { Null or opposite } \\
\text { findings }\end{array}$ \\
\hline & & $\begin{array}{l}\text { Employment/ } \\
\text { economic } \\
\text { development }\end{array}$ & & $\begin{array}{l}\text { girls not in } \\
\text { school }\end{array}$ & $\begin{array}{l}\text { Health } \\
\text { clinics } \\
\text { Home/ } \\
\text { homework } \\
\text { w/ parents }\end{array}$ & & & $\begin{array}{l}\text { vocational training, } \\
\text { micro-grants, and } \\
\text { social supports }\end{array}$ & & & $\begin{array}{l}\text { received social } \\
\text { support, } \\
\text { relationship power, } \\
\text { contraception, } \\
\text { sexual activity, } \\
\text { HIV, HSV, } \\
\text { unintended } \\
\text { pregnancy, or } \\
\text { sexual risk }\end{array}$ \\
\hline \multicolumn{12}{|c|}{ The Empowerment and Livelihood for Adolescents program (ELA) } \\
\hline $\begin{array}{l}\text { Bandiera, } 2012 \\
\text { Bandiera et al., } \\
2017 \text { [64] }\end{array}$ & $\mathrm{RCT}$ & $\begin{array}{l}\text { Violence } \\
\text { prevention } \\
\text { Employment } \\
\text { SRH/HIV } \\
\text { Gender } \\
\text { equality }\end{array}$ & Uganda & $\begin{array}{l}14-\text { to } 20- \\
\text { year-old } \\
\text { girls }\end{array}$ & $\begin{array}{l}\text { Community } \\
\text { orgs }\end{array}$ & $\begin{array}{l}150 \\
\text { communities; } \\
100 \text { treatment } \\
\text { and } 50 \\
\text { control }\end{array}$ & $\begin{array}{l}T x=3964 \\
C=2002\end{array}$ & $\begin{array}{l}\text { Safe local } \\
\text { community clubs } \\
\text { for young women, } \\
\text { vocational and life } \\
\text { skills trainings, and } \\
\text { recreational } \\
\text { activities }\end{array}$ & $\begin{array}{l}\text { Improved knowledge } \\
\text { related to pregnancy } \\
\text { and HIV, self-report } \\
\text { always uses condom } \\
\text { Reduced married or } \\
\text { cohabitating, having } \\
\text { sex unwillingly in the } \\
\text { past year, and having } \\
\text { children } \\
\text { Increased self- } \\
\text { employment }\end{array}$ & 2 years & $\begin{array}{l}\text { NO impact on } \\
\text { satisfaction with } \\
\text { earnings or wage } \\
\text { employment }\end{array}$ \\
\hline \multicolumn{12}{|l|}{ BALIKA } \\
\hline $\begin{array}{l}\text { Amin et al., } \\
2016 \text { [65] }\end{array}$ & $\mathrm{RCT}$ & $\begin{array}{l}\text { SRH/HIV } \\
\text { Gender } \\
\text { equality } \\
\text { Education } \\
\text { Employment }\end{array}$ & Bangladesh & $\begin{array}{l}12-\text { to } 18- \\
\text { year-old } \\
\text { girls }\end{array}$ & $\begin{array}{l}\text { School } \\
\text { Community } \\
\text { orgs }\end{array}$ & $\begin{array}{l}96 \\
\text { communities: } \\
\mathrm{Tx}=72 \\
\mathrm{C}=24\end{array}$ & $9000+$ & $\begin{array}{l}\text { Educational } \\
\text { support delivered } \\
\text { in four versions: } \\
\text { tutoring, gender } \\
\text { awareness, } \\
\text { livelihood skills, } \\
\text { and community } \\
\text { engagement, each } \\
\text { with different } \\
\text { activities }\end{array}$ & $\begin{array}{l}\text { Reduced child } \\
\text { marriage, increased } \\
\text { SRH knowledge. } \\
\text { Increased school } \\
\text { attendance, private } \\
\text { tutors, experience in } \\
\text { working for pay } \\
\text { (gender awareness and } \\
\text { livelihoods } \\
\text { interventions), } \\
\text { indicators of social } \\
\text { freedoms and reduced } \\
\text { harassment outside of } \\
\text { home (gender } \\
\text { awareness and } \\
\text { education interventions) }\end{array}$ & 18 mos. & $\begin{array}{l}\text { No impact on no. } \\
\text { hours worked, } \\
\text { earnings, } \\
\text { harassment inside } \\
\text { the home/family or } \\
\text { birth control. } \\
\text { Livelihood } \\
\text { intervention had no } \\
\text { impact on social } \\
\text { freedoms. }\end{array}$ \\
\hline
\end{tabular}




\begin{tabular}{|c|c|c|c|c|c|c|c|c|c|c|c|}
\hline Citation & $\begin{array}{l}\text { Evaluation } \\
\text { design }\end{array}$ & Sectors & Country & $\begin{array}{l}\text { Recipient } \\
\text { age }\end{array}$ & Setting & Clusters & $\begin{array}{l}\text { Sample } \\
\text { size }\end{array}$ & Brief description & Outcomes & $\begin{array}{l}\text { Follow- } \\
\text { up period }\end{array}$ & $\begin{array}{l}\text { Null or opposite } \\
\text { findings }\end{array}$ \\
\hline \multicolumn{12}{|l|}{ ACTIVITAL } \\
\hline $\begin{array}{l}\text { Andrade et al., } \\
2014 \text { [66] }\end{array}$ & $\mathrm{RCT}$ & $\begin{array}{l}\text { Physical } \\
\text { fitness }\end{array}$ & Ecuador & $\begin{array}{l}12 \text { - to } 15- \\
\text { year-olds }\end{array}$ & School & 20 schools & $\begin{array}{l}\mathrm{Tx}=550 \\
\mathrm{C}=533\end{array}$ & $\begin{array}{l}\text { Classroom } \\
\text { curriculum, } \\
\text { physical activities, } \\
6 \text { workshops for } \\
\text { parents, events with } \\
\text { prominent athletes, } \\
\text { and new walking } \\
\text { trail }\end{array}$ & $\begin{array}{l}\text { Increased objective } \\
\text { measures of physical } \\
\text { fitness and prevented } \\
\text { decline in physical } \\
\text { activity over time }\end{array}$ & 2 years & $\begin{array}{l}\text { No effects on } \\
\text { screen time or BMI }\end{array}$ \\
\hline \multicolumn{12}{|c|}{ I (Yo), Think (Pienso), Feel (Siento), and Act (Actuo) } \\
\hline $\begin{array}{l}\text { Araya et al., } \\
2013 \text { [75] }\end{array}$ & $\mathrm{RCT}$ & Mental health & Chile & $\begin{array}{l}13 \text { - to } 15- \\
\text { year-olds }\end{array}$ & School & $\begin{array}{l}26 \\
\text { communities }\end{array}$ & $\begin{array}{l}T x=1288 \\
C=1376\end{array}$ & $\begin{array}{l}\text { Ten group sessions } \\
\text { covering coping } \\
\text { with thoughts and } \\
\text { emotions and } \\
\text { problem-solving } \\
\text { Booster sessions at } \\
2 \text { and } 7 \text { months } \\
\text { after last session }\end{array}$ & & $\begin{array}{l}3,12 \\
\text { mos. }\end{array}$ & $\begin{array}{l}\text { No meaningful } \\
\text { outcomes } \\
\text { Effect on anxiety } \\
\text { was statistically } \\
\text { significant, but not } \\
\text { considered } \\
\text { clinically relevant }\end{array}$ \\
\hline
\end{tabular}

